\title{
Effect of Boron on the Hardenability of High-Purity Alloys and Commercial Steels
}

\author{
By Thomas G. Digges, Carolyn R. Irish, and Nesbit L. Carwile
}

\begin{abstract}
A study was made of the action of boron in relation to the hardenability of high-purity alloys varying in carbon content. The effectiveness of boron in enhancing the hardenability of these alloys and certain steels is believed to be due to its action in retarding the rate of nucleation of ferrite and carbide while in solid solution in austenite. The hardenability of the boron-treated alloys, as determined in terms of the critical cooling rate of small specimens austenitized at a wide range of temperatures, varied with the prior history and with the carbon content. The hardenability of a commercial boron-treated steel, as determined by the end-quench test, was also sensitive to prior thermal treatments. Boron was lost in the decarburized zone of commercial steels, and its rate of diffusion apparently is of the same order of magnitude as that of carbon. The heat treatment of specimens of the alloys and steels to produce a boron constituent and the microstructures of the alloys as cast and as homogenized are described.
\end{abstract}

\section{Introduction}

In a previous investigation [1], ${ }^{1}$ evidence was obtained that the effectiveness of boron in enhancing the hardenability of certain steels depended upon the form of the boron at the time of quenching and not necessarily on the total amount of boron present. This observation was based on a determination of hardenability by the end-quench test. As the study was carried out during a period of national emergency, but little attention could be given to the mechanism of the effect of boron on hardenability. The present investigation was made as a further study of the hardenability of boron-treated alloys and steels with particular attention directed to the action of boron on the hardenability of these materials.

High-purity alloys consisting of: (1) iron and boron, (2) iron and carbon, without and with boron, and (3) iron, carbon, and manganese, without and with boron were prepared in the laboratory, and commercial open-hearth steels were procured for use in this investigation. Determination was made of the hardenability in terms of the critical cooling rate of the iron-carbon

\footnotetext{
1 Figures in brackets indicate the literature references at the end of this paper.
}

and iron-carbon-manganese alloys when quenched from various temperatures. The end-quench test also was used for evaluating the hardenability of the iron-carbon-manganese alloys and the commercial steels. A metallographic study was made of specimens prepared from the alloys in the conditions as cast, as forged and homogenized, and as heat treated in various ways to precipitate a boron constituent. Experiments also were made to determine whether boron was lost during the decarburization of commercial steels and for determining the rate of diffusion of boron in austenite of these steels.

\section{Previous Investigations}

Considerable work has been carried out by different investigators in studying the iron-boron equilibrium system. The published diagrams $[2,3]$, however, were of little value in the present study because of inconsistencies, especially in the solubility of boron in the alpha and gamma fields, and deficiency in information on alloys containing the relatively low amount of boron now used commercially in boron-treated steels $(0.0005$ to 0.005 percent of boron).

The action of boron in increasing the harden- 
ability of steel is not definitely known, but tentative explanations have been reported in the literature. These theories may be classified on the basis that the improvement is due to boron in solid solution in austenite, and a reaction of boron with some other element to change the condition of the latter.

Grange and Garvey [4] assumed the presence of boron in steel in both an effective and an ineffective form. The effective form is capable of dissolving in austenite, whereas the ineffective boron does not enter into austenite solid solution. The small boron atom is pictured as forming an interstitial solid solution with gamma iron. The boron atoms are preferentially located in the grain boundaries of the austenite just prior to its transformation, and their presence lowers the rate of grain boundary nucleation and thus increases hardenability. As boron has a relatively low solubility in austenite, some of the boron atoms may be precipitated as some compound and thus form a "film" at the austenite grain boundaries that is supersaturated with respect to these atoms. This precipitate seemingly occurs rapidly and in advance of the usual transformation of austenite to ferrite; only those boron atoms that remain in solid solution are effective in decreasing the rate of nucleation of ferrite and hence in increasing the time required for austenite to transform. Heating steel at a high temperature for a long time may convert effective into ineffective boron; the latter may be some stable chemical compound of boron that gradually forms at high temperature. Lippert [5] stated that boron, similar to any other alloying element, must be in solid solution to be effective in increasing hardenability.

Chandler and Bredig [6] were of the opinion that nitrides act as nucleating agents in the decomposition of austenite, particularly for the rejection of ferrite. The hardenability effect of boron, either alone or in combination with other elements, appears to be the influence of a fluxing agent upon the particle size of nitrides of other elements, such as those of silicon, aluminum, titanium, and zirconium. Thus boron converts particles of harmful critical size into particles of larger size unable to effect nucleation. Corson [7] assumed that boron increases hardenability by its action in removing something in the steel (possibly free nitrogen) that exists in very small amounts by weight and which has a deleterious effect on hardenability. Bain [8] apparently was of the opinion that boron has little effect as an alloying element but more likely acts as a sort of cleansing agent, perhaps in some connection with the nitrogen content of the steel. Dean and Silkes [9] were inclined to believe that the effect of boron on hardenability was due to a dispersion rather than a solution in austenite. Presumably the boron in excess of the small amount required for maximum hardenability reacts with some other constituent in the steel.

Digges and Reinhart [1] found no definite correlation between the amount of boron added or retained in experimental (induction melted) and commercial open-hearth steels and the hardenability as determined by the end-quench test. In many of the aluminum-killed experimental steels, the optimum hardenability was obtained with small additions of boron $(0.001 \%$ or less retained), whereas in other steels the hardenability increased continuously with increase in boron (about 0.0015 to $0.006 \%$ ). In still other steels, the addition of boron as a simple or complex intensifier was either without effect or impaired the hardenability. The hardenability of boron-treated steels varied also with the state of deoxidation and with the nitrogen content. High acid-soluble nitrogen (sulfuric acid) was usually detrimental to the effect of boron on hardenability, but it was possible to retain the effect in highnitrogen steels (low-soluble nitrogen) by fixing the nitrogen with strong nitride-forming elements, such as titanium. With the commercial borontreated steels, the magnitude of the hardenability effect was independent of the amount of boron added or retained and the chemical composition of the intensifiers used.

Boss [10] speculated that boron increases hardenability of steel by the removal of the last trace of oxygen, but boron itself is harmful to hardenability; a small amount of oxygen is also detrimental to hardenability. Grossmann [11] suggested the possibility of the boron being present, at least in part, as stable carbides.

\section{Alloys and Steels Used}

The chemical compositions of the high-purity alloys and the steels used are given in table 1.

In preparing the alloys, one lot of electrolytic iron was used as the base material. Melting was 
TABLE 1. Chemical composition of the alloys and steels used

\begin{tabular}{|c|c|c|c|c|c|c|c|c|c|c|c|c|c|c|c|c|c|}
\hline \multirow{3}{*}{ Identification } & \multicolumn{17}{|c|}{ Percentage by weight as determined- } \\
\hline & \multicolumn{6}{|c|}{ Chemically } & \multicolumn{8}{|c|}{ Spectrographically 1} & \multicolumn{3}{|c|}{ By vacuum fusion } \\
\hline & $\mathrm{C}$ & Mn & $\mathrm{P}$ & $\mathrm{s}$ & $\mathrm{Si}$ & $\mathrm{B}$ & Mn & $\mathrm{Si}$ & $\mathrm{Ni}$ & Co & $\mathrm{Cu}$ & $\mathrm{Al}$ & $\mathrm{Cr}$ & $\mathrm{B}$ & $\mathrm{O}$ & $\mathrm{N}$ & $\mathrm{H}$, \\
\hline \multicolumn{18}{|c|}{ IRON-BORON ALLOYS } \\
\hline $\begin{array}{l}\text { B3 } \\
\text { B4 }\end{array}$ & $\begin{array}{r}<0.01 \\
<.01\end{array}$ & ... & $\begin{array}{l}-.- \\
-.-\end{array}$ & -.. & -.. & $\begin{array}{c}0.0028 \\
.011\end{array}$ & $\begin{array}{r}0.002 \\
.002\end{array}$ & $\begin{array}{l}<0.01 \\
<.01\end{array}$ & $\begin{array}{r}0.013 \\
.012\end{array}$ & $\begin{array}{r}0.008 \\
.008\end{array}$ & $\begin{array}{r}0.003 \\
.004\end{array}$ & $\begin{array}{c}0.003 \\
<.001\end{array}$ & $\begin{array}{l}<0.001 \\
<.001\end{array}$ & $\ldots$ & $\begin{array}{r}0.011 \\
.008\end{array}$ & 0.001 & $\begin{array}{r}0.0001 \\
.0003\end{array}$ \\
\hline \multicolumn{18}{|c|}{ IRON-CARBON ALLOYS } \\
\hline B8. & 0.32 & ... & 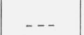 & 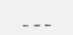 & ... & ${ }^{2}$ None & 0.002 & $<0.01$ & 0.013 & 0.008 & 0.002 & 0.001 & $<0.001$ & ${ }^{3} \mathrm{ND}$ & 0.003 & 0.001 & 0.0003 \\
\hline B6 _. & .32 & -.. & $<0.001$ & 0.002 & ...- & 0.0021 & .002 & $<.01$ & .011 & .008 & .001 & .001 & $<.001$ & ... & .003 & .001 & .0003 \\
\hline $\mathrm{B} 7$ & .50 & ... & ... & ... & ... & None & .001 & .002 & .010 & .007 & .001 & ${ }^{3} \mathrm{ND}$ & ND & ND & .002 & .001 & .0002 \\
\hline B12 & .54 & -.. & ... & ... & ... & None & .002 & $<.01$ & .010 & .007 & .002 & $<.001$ & $<.001$ & ND & .001 & .001 & .0001 \\
\hline $\mathrm{B} 2 \ldots$ & .47 & ... & ... & ...- & ... & .0020 & .001 & .002 & .013 & .008 & .001 & ND & ND & $\ldots$ & .004 & .001 & .0003 \\
\hline B10 & .70 & -.. & ... & ... & ... & None & .002 & .025 & .009 & .007 & .003 & .008 & $<.001$ & 0. 0004 & .001 & .0005 & .0004 \\
\hline B5 & .74 & -.- & -.. & -.. & -.. & .0028 & .002 & $<.01$ & .011 & .007 & .001 & $<.001$ & $<.001$ & -.. & .005 & .001 & .0004 \\
\hline \multicolumn{18}{|c|}{ IRON-CARBON-MANGANESE ALLOYS } \\
\hline B13 & 0.42 & 0.67 & $<0.001$ & 0.002 & 0.087 & None & ... & 0.11 & 0.012 & 0.008 & 0.001 & 0.041 & $<0.001$ & ND & 0.002 & 0.001 & 0.0001 \\
\hline B14_.- & .41 & .64 & $<.001$ & .002 & .096 & 0.0024 & 0.68 & .09 & .010 & .008 & .001 & .003 & ND & 0.0025 & .001 & .001 & .0001 \\
\hline \multicolumn{18}{|c|}{ COMMERCIAL STEELS 4} \\
\hline C15 & .043 & 1. 58 & 0.020 & 0.019 & 0.31 & ${ }^{5}$ None & -.. & -.. & -.. & -.. & -.. & -.. & -.. & & --. & -.- & - . - \\
\hline $\mathrm{C} 9 \ldots$ & .43 & 1. 58 & .019 & .019 & .32 & 0.0003 & -.. & -.. & -.. & -.. & -.. & $\ldots$ & -.. & 0.0004 & -.. & ... & -..... \\
\hline C11.. & .42 & 1. 59 & .019 & .018 & .32 & .0011 & -.. & ... & -.. & -.. & -.- & -.. & -.. & .0014 & -.- &.- & -..-- \\
\hline C12 & .43 & 1. 56 & .020 & .019 & .31 & .0022 & ...- & ... & ... & ... & ... & $\ldots$ & ... & .0020 & ... & ... & (...... \\
\hline C14 .... & .43 & 1. 59 & .018 & .019 & .32 & .0036 & ... & ... & .... & ... & ... & ... & -... & -.0040 & ... & ... & ...... \\
\hline C19... & .43 & 1. 58 & . 019 & .018 & .31 & .0001 & ... & -.- & -.. & ... & -.. & -.. & -.. & .0003 & -.. & -.. & ...... \\
\hline
\end{tabular}

${ }^{1} \mathrm{~V}, \mathrm{Mo}, \mathrm{Sn}$, and $\mathrm{W}$ were searched for in all of the alloys and Ti and $\mathrm{Zr}$ in most of the alloys. These elements were not detected, but a small amount of Be was found in B13.

${ }^{2}$ None denotes not added.

${ }^{3}$ ND denotes not detected.

${ }_{4}^{4}$ Split open hearth heat. The boron additions were made with Grainal No. 79 (C9 and C11), Ferroboron (C12 and C14), and Grainal No. 1 (C19) in the mold.

5 Trace (less than $0.0001 \%$ ) boron was detected by chemical analysis.

by induction heating of the charge in crucibles of high-purity magnesia, except for the two alloys containing manganese (B13 and B14), which were melted in commercial crucibles of beryllia. Additions as required were made of carbon and electrolytic manganese in the initial charge, whereas the boron was added to the molten metal as commercial ferroboron containing about 12 percent of boron. The heats were not deoxidized with aluminum or silicon. Melting and subsequent solidification of the ingot were carried out in vacuo obtained by means of a mechanical vacuum pump rated to attain a vacuum of $0.02 \mu$ of mercury. In most cases, the system was vacuum tight as was indicated by the manometer after standing for 12 to $15 \mathrm{hr}$. without operating the pump. The boron additions were made by means of a special holder without disturbing the vacuum.

The manganese, nickel, and cobalt contents were approximately the same for each alloy, except for two (B13 and B14) in which the manganese was intentionally added. These impurities and the sulfur and phosphorus contents, as determined for several of the alloys, were about the same as those contained in the electrolytic iron used as the base material. In some cases, there was some pick-up in silicon and aluminum (incident to the melting operation) especially in the alloys prepared in the commercial crucibles. The results of the vacuum fusion analyses showed that the oxygen and nitro- 
gen contents of the alloys were low except for the relatively high values for oxygen of the two ironboron alloys (B3 and B4) not treated with carbon; 0.004 to 0.005 percent of oxygen was obtained in the boron-treated alloys B2 and B5.

Some of the ingots of the high-purity alloys were hot forged to a range of about three-quarters to one-third of their original diameters. The outer surfaces of these forged bars were removed by machining prior to carrying out a homogenizing treatment by heating in vacuum at temperatures ranging from $1,700^{\circ}$ to $1,900^{\circ} \mathrm{F}$ for varying periods. The evacuated tube containing the bars was cooled from the high temperature in air. Microscopic examination of the cross section of the bars after the homogenizing treatment indicated a fair degree of uniformity in distribution of the carbon. Specimens subsequently used for test purposes were prepared from the original ingots (as cast) or from the bars as homogenized.

The commercial steels were from the same "split" open-hearth heat as that used and described in a previous investigation [1]. The boron additions were made in the mold with Grainal No. 79, (Steel C9 and C11), Ferroboron (Steels
C12 and C14), and Grainal No. 1 (Steel C19). These steels were received in the form of hot rolled $1 \frac{1}{4}$-in. rounds.

\section{Austenite Grain Size}

Since the hardenability of most steels is influenced by the size of the grains at the time of quenching, a determination was made of the grain size established at the quenching temperatures of each alloy and steel used in carrying out the critical cooling rate and end-quench tests. Grain size measurements were made by the method described by Jeffries [12] or by estimating the grain number by comparing the microscopic image at 100 diameters with an American Society for Testing Materials standard grain size chart.

The results obtained on the small specimens used for determining the critical cooling rate are summarized in table 2 and illustrated by typical photomicrographs in figures 1 and 2 . In some of the quenched specimens, the parent austenite grains could be revealed by a contrast etch of the martensite (fig. 1), or by the presence of small amounts of fine pearlite located at their boundaries (fig. 2, A).

TABle 2. Austenite grain size of the alloys

Small specimens, initially as homogenized or as cast, were heated rapidly to the required temperature, held at, this temperature for 15 min. before cooling at various rates. The same specimens were used to determine critical cooling rates.

\begin{tabular}{|c|c|c|c|c|c|c|c|c|c|c|}
\hline \multirow{2}{*}{ Identification } & \multicolumn{3}{|c|}{ Percentage } & \multicolumn{7}{|c|}{ Average number of grains per square inch at times 100 diameters, at- } \\
\hline & $\mathrm{C}$ & B & $\mathrm{Al}$ & $1,425^{\circ} \mathrm{F}$ & $1,500^{\circ} \mathrm{F}$ & $1,600^{\circ} \mathrm{F}$ & $1,700^{\circ} \mathrm{F}$ & $1,800^{\circ} \mathrm{F}$ & $1,900^{\circ} \mathrm{F}$ & $2,000^{\circ} \mathrm{F}$ \\
\hline
\end{tabular}

INITIALLY AS HOMOGENIZED

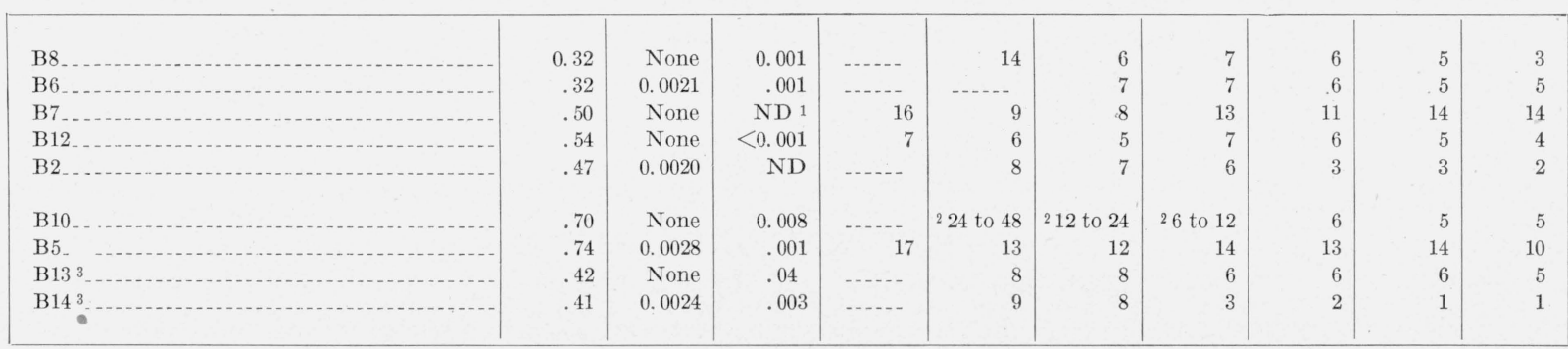

INITIALLY AS CAST

\begin{tabular}{|c|c|c|c|c|c|c|c|c|c|c|}
\hline B6 . & 0.32 & 0.0021 & 0.001 & 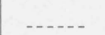 & $\ldots$ & 224 to 48 & 11 & 11 & 13 & 13 \\
\hline B2 & .47 & .0020 & ND & ..... & 10 & 9 & 4 & 4 & 3 & 2 \\
\hline B5 & .74 & .0028 & $<.001$ & 224 to 48 & 224 to 48 & 224 to 48 & 212 to 24 & 212 to 24 & 26 to 12 & 26 to 12 \\
\hline
\end{tabular}

1 ND denotes not detected.

${ }^{2}$ Estimated.

3 The alloy also contained approximately 0.65 percent of manganese and 0.10 percent of silicon. 
Although an attempt was made to heat the specimens relatively rapidly through the transformation temperature range, the heating rates varied to some degree with the different specimens and with the maximum temperature attained. As previously shown [13], the grain size at temperatures somewhat above $\mathrm{Ac}_{3}$ of high-purity ironcarbon alloys varied with the rate of heating through the transformation temperature range; the austenite grain size increased markedly with a decrease in rate of heating. Variations were sometimes obtained in the grain size of the different specimens of a selected alloy, especially B2 and $\mathrm{B} 10$, when heated to the same temperature, as is illustrated for alloy B12 in figure 1, C and F, and occasionally a wide variation in the size of the grains was obtained in the same specimen (fig. 1, D and E). Grain-size measurements made on the latter specimen are practically meaningless. In some cases, the variation in grain size at a selected temperature of different specimens of the same alloy was as great or greater than that due to the range in temperature used. (Compare fig. 1, C and $\mathrm{F}$ with fig. 2, D and F.) Because of these conditions, the same specimens were used for determining the austenite grain size and the hardenability. That the austenite grain size of one of the alloys (B13) is affected by the rate of heating or by prior thermal treatment is shown by the photomicrographs of figure 2 . The grain size at $1,500^{\circ}, 1,700^{\circ}$, and $1,900^{\circ} \mathrm{F}$ of an end-quench specimen is shown in figure $2, \mathrm{~A}, \mathrm{~B}$, and $\mathrm{C}$ and that of considerably smaller specimens (used in determining the critical cooling rate) in figure 2 , $\mathrm{D}, \mathrm{E}$, and F. The grain size of the end-quench specimen increased with a change in temperature from $1,500^{\circ}$ to $1,700^{\circ} \mathrm{F}$, but there was practically no further increase in size when heated to $1,900^{\circ}$ F. The average grain size of the small specimens was unaffected by this range in austenitizing temperatures. The same specimen was used for end-quenching from each temperature, and the small specimens were prepared from this bar after the quench from $1,900^{\circ} \mathrm{F}$. The bar was normalized at $1,650^{\circ} \mathrm{F}$ prior to each quenching treatment. The specimen for end-quenching was heated in a furnace at the desired temperature for $45 \mathrm{~min}$ (total time in furnace), and it required an estimated time of 10 to $15 \mathrm{~min}$ to attain the temperature of the furnace. The small specimens were heated from room temperature to the austeni- tizing temperature in approximately 2 min and were held at temperature for $15 \mathrm{~min}$ (in furnace for $17 \mathrm{~min}$ ) before quenching; it required about 6 to 8 sec to heat each specimen through the transformation temperature range. All specimens had an initial structure of fine pearlite and ferrite, but variations thus existed in the rate of heating and time at the austenitizing temperature of the two series. It is noteworthy that the grain size established at $1,500^{\circ} \mathrm{F}$ was somewhat finer in the large than in the small specimen (fig. 2, A and D), although the rate of heating was slower and the time at temperature was greater for the large than for the small specimens; the grain size should increase, not decrease, with time at austenitizing temperature. The trend for the grain size at $1,500^{\circ} \mathrm{F}$ of this iron-carbon-manganese alloy containing 0.04-percent aluminum (B14) to increase with the faster rate of heating is the reverse of that observed previously in high-purity ironcarbon alloys. It was shown [13], however, that the austenite grain size at the temperature ordinarly used in hardening an aluminum killed commercial steel containing 0.5 -percent carbon increased with increase in rate of heating through the transformation temperature range.

Intermediate or coarse grains were established at each austenitizing temperature of each alloy (table 2 and fig. 18). This is to be expected, as the alloys were of relatively high purity with the presence of only small amounts, if any, of the grain-refining elements (other than carbon) except for the 0.04-percent aluminum in B13.

The austenite grain size of some of the alloys varied with the initial condition of the specimens (table 2). At a selected temperature, the size of the grains in an initially homogenized specimen was either approximately the same or coarser than that of the same alloy initially as cast.

With an initial structure as homogenized, the average size of the austenite grains of alloys B7, B12, B13 (all without boron) B6 and B5 (each with boron) was not significantly affected by the range in austenitizing temperatures used. However, there was some increase in grain size of alloys $\mathrm{B} 8$ and B10 (without boron), and B2 and B14 (with boron) with a change from the lower to the higher part of the range in austenitizing temperatures.

With an initial structure as cast, the average size of the austenite grains of alloys B6, B2, and B5 
(all with boron) was somewhat finer at the lower than at the higher austenitizing temperatures.

Apparently, boron had no consistent effect on the austenite grain size and coarsening temperature of these high-purity alloys.

\section{Hardenability}

\section{Procedure}

Numerous methods have been proposed and used for determining the hardenability of steel. The selection of a method depends largely upon the nature of the information desired and range in hardenability of the steels or alloys. The standard end-quench test is widely used commercially for measuring the hardenability of low alloy. steels (intermediate hardenability), but it is not well suited for the shallow hardening type (plain carbon) or for the deep hardening alloy steels, such as those that harden through in $3 / 4$-in. rounds or larger sections by cooling in air.

In carrying out a fundamental study of hardenability, it is a common practice to measure either the cooling rate at a selected temperature or the cooling time or rate through a temperature interval during the quenching operation, and then evaluate the cooling time or rate in terms of the structure or hardness of the quenched specimen. However, different parameters, including temperature intervals, structures, and hardnesses have been used by various investigators. French [14] used the cooling rate at $1,330^{\circ} \mathrm{F}$, Boeghold and Weinman [15] at $1,300^{\circ} \mathrm{F}$. and the time to cool from $1,350^{\circ}$ to $900^{\circ} \mathrm{F}$., and Post, Fetzer, and Fenstermacher [16] used the rate at $1,000^{\circ} \mathrm{F}$. to evaluate hardenability; values for the cooling rate at $1,300^{\circ} \mathrm{F}$. are included in the chart prepared by the American Society for Testing Materials [17] for presenting data obtained in the endquench test. Grossmann [18] and coworkers used the time required to cool from the quenching temperature to that half way down to the temperature of the quenching medium, and they arbitrarily selected a structure consisting of 50-percent martensite and 50-percent pearlite (ferrite and carbide) as the division between the hardened and unhardened condition. These data have been used extensively in computing the hardenability from the chemical compositions of the steels.

The isothermal transformation diagrams ( $\mathrm{S}$ or T'T'T curves) for numerous steels [19] show that the decomposition of austenite to aggregates of ferrite and carbide (pearlite) is most rapid in the temperature range of about $1,110^{\circ}$ to $930^{\circ} \mathrm{F}$ (nose of curve) but in some steels, notably the deep hardening type containing high molybdenum, the nose of the isothermal transformation curve may occur in the lower part or below this range. To completely harden a steel by quenching, it is essential to cool with sufficient rapidity to prevent its austenite from transforming in this temperature range. If by a continuous quench to approximately room temperature, the austenite is cooled through the range of $1,110^{\circ}$ to $930^{\circ} \mathrm{F}$ without decomposing, it remains unchanged until a temperature is reached that is favorable for its transformation to martensite. This applies to most steels in which pearlite rather than bainite limits the formation of martensite. At some cooling rate, called the critical cooling rate, the austenite of a steel that is capable of hardening by quenching just begins to transform at the nose of the S-curve. The critical cooling rate, therefore, is an index to hardenability. The slower the critical cooling rate, the deeper is the hardening of the steel. Published data show that the temperature of the initial transformation of austenite to martensite is not affected by the rate of cooling, that is, the start of the $\mathrm{Ar}^{\prime \prime}$ or Ms temperature is not depressed by rapid cooling.

A determination of the critical cooling rate was used at this Bureau in a study of the hardenability of high-purity alloys of iron and carbon 120]. With suitable equipment the method is capable of producing results of a high degree of accuracy, and it is applicable for alloys with a wide range in hardenability. This method was, therefore, selected for use in the present study. In addition, the standard end-quench test was used for evaluating the hardenability of the two alloys containing manganese (B13 and B14, table 1) and for determining the effects of quenching temperature and initial structure on hardenability of the commercial steels.

\section{(a) Critical Cooling Rate}

The apparatus and procedures used for obtaining time-temperature cooling curves were similar to those described in some detail in a previous report [20]. The essential features consisted of using specimens approximately $1 / 10 \mathrm{in}$. square by 0.04 in. thick with one wire of a 32 -gage chromelalumel thermocouple spot welded to the center of 
a flat face and the other wire welded to the opposite face. The specimen was heated rapidly (usually the specimen attained the austenitizing temperature within $2 \mathrm{~min}$ ) in an atmosphere of dry nitrogen, or in vacuo, to the required temperature and held at temperature for $15 \mathrm{~min}$. before quenching directly in helium. Cooling of the specimen was recorded photographically by means of an Einthoven string galvonometer apparatus, and a time-temperature cooling curve was plotted from this record. Metallographic examination was made of the cross section of the quenched specimen a short distance from the points of contacts of the thermocouple wires, and the structure of the specimen was correlated with its cooling time or rate. The quenching temperature used ranged from $1,425^{\circ}, 1,500^{\circ}$, or $1,600^{\circ}$ to $2,000^{\circ} \mathrm{F}$, depending upon the carbon content of the alloy.

The amount of fine pearlite (nodular troostite) or bainite contained in the quenched specimen was estimated as 0.0 percent, trace, $0.2,1.0$ or over 1.0 percent. The photomicrographs of figure $3, \mathrm{~A}, \mathrm{~B}$, and $\mathrm{C}$ were used as a "standard" in making this estimate. In a continuous quench of these high-purity alloys, the initial transformation product of austenite, which was formed at the nose of the S-curve was fine pearlite as is illustrated in figure 3 ; some bainite also was formed in some of the specimens of the two alloys (B13 and B14), which contained about 0.7-percent manganese.

\section{(b) End-Quench Test}

The procedure as recommended by the American Society for Testing Materials [17] was regularly followed in making the standard end-quench test, except that when higher quenching temperatures than those usually recommended were used, the quenched bar was ground to a depth of 0.030 to $0.045 \mathrm{in}$. preparatory to making the hardness measurements; with the high-purity alloys (B13 and B14), the same specimen was used for each of the three end-quenching treatments. These specimens were not exactly round at the time of carrying out the last two treatments, as they contained either two or four flats ground on the surface for use in the prior determination of hardness. A special fixture was used for positioning the specimen for making the Rockwell hardness measurements.

\section{Results}

\section{(a) Iron-Carbon Alloys}

Critical Cooling Rate. A photographic record of the time-temperature relationship, which was obtained with each specimen during the quencn, permits an evaluation of these data in terms of the cooling time or rate at any selected temperature or temperature interval within the range corresponding to that of the start and finish of the quench (austenitizing and approximately room temperature, respectively).

Specimens Initially as Homogenized. The relation of the time required to cool specimens through three temperature ranges to the structures of the iron-carbon alloys is given in figures 4 to 10 . These specimens were prepared from initially homogenized bars and were quenched from various temperatures. In these figures, the curves represent the relation of the cooling time for the formation of 0.2-percent fine pearlite (critical cooling time) to the quenching (austenitizing) temperature. The values for the specimens, which were cooled too rapidly to allow the critical amount of austenite to transform (at the nose of the S-curve), should fall below the curve, whereas the values for the specimens containing more than 0.2-percent pearlite should lie above the curve. There were some inconsistencies in this relation that may have been caused by a variation in grain size at the austenitizing temperature or by chemical inhomogeneity. As is illustrated in figure 5, however, no definite correlation was obtained between cooling time and structure of initially homogenized specimens of the alloy B6 containing 0.32 -percent carbon and 0.0021-percent boron when quenched from temperatures ranging from $1,600^{\circ}$ to $2,000^{\circ} \mathrm{F}$. It is believed that the relative ineffectiveness of boron in improving the hardenability of some of the specimens may be due to a change in the form of boron in the austenite brought about during the hot-working (forging) or homogenizing process. Evidence supporting this view will be discussed later in connection with figure 15 .

The relation of critical cooling time to quenching temperature of an alloy was quite similar for each of the three temperature intervals used, as is shown by the shape of the curves. This is to be expected because of the exponential type of cooling curve that was obtained on quenching the 
small specimens from the austenitizing temperature in gas at a rate sufficiently fast to prevent less than about 5 percent of the austenite transforming to relatively soft products. Thus a determination of the cooling time through any one of the three temperature ranges used appears to be as suitable as the remaining two for correlating with the microstructure in evaluating the hardenability of these alloys. Obviously, however, the values used to express the hardenability in terms of the critical cooling time or rate will vary with the temperature ranges used. Since a determination of the cooling rate through the range, $1,110^{\circ}$ to $930^{\circ} \mathrm{F}$ (nose of S-curve) was used in previous investigations to evaluate the hardenability of high purity iron-carbon alloys, this temperature range was again selected for use in the present study. The critical cooling rate, therefore, is taken as the average cooling rate between $1,110^{\circ}$ and $930^{\circ} \mathrm{F}\left(600^{\circ}\right.$ to $\left.500^{\circ} \mathrm{C}\right)$ which produced in, the quenched specimen a structure of martensite with fine pearlite in an amount estimated to be 0.2 percent.

The relation of critical cooling rate to quenching temperature of initially homogenized specimens of iron-carbon alloys, without and with boron, is shown in figure 11. For alloys without boron, the critical cooling rate decreased continuously with increase in quenching temperature when the carbon content was 0.32 percent (B8), but the critical cooling rate of the alloys with 0.50 - or 0.54 -percent carbon (B7 and B12) was not appreciably affected by changes in quenching temperatures within the range from $1,425^{\circ}$ to $2,000^{\circ} \mathrm{F}$. With 0.70 -percent carbon (B10), the critical cooling rate was approximately constant when the alloy was quenched from temperatures within the range of about $1,425^{\circ}$ to $1,600^{\circ} \mathrm{F}$, the rate decreased rapidly with change in quenching temperature from about $1,600^{\circ}$ to $1,800^{\circ} \mathrm{F}$ and then less rapidly with a further increase in quenching temperature.

For the alloys with boron, the critical cooling rate decreased continuously with increase in quenching temperature when the carbon was 0.47 percent (B2), but with 0.74-percent carbon (B5) the rate was constant for quenching temperatures up to $1,600^{\circ} \mathrm{F}$. The critical cooling rate of the latter alloy decreased somewhat with increase in quenching temperature from $1,600^{\circ}$ to $2,000^{\circ} \mathrm{F}$. As previously stated, no consistent relationship was shown between the cooling rate and structure produced by quenching initially homogenized specimens of the 0.32 -percent carbon-0.0021-percent boron alloy (B6).

The influence of boron on the hardenability of alloys with about 0.5 - and 0.7 -percent carbon is shown by a comparison of the positions of the curves of figure 11. The improvement in hardenability of the boron-treated alloys was confined principally to the high range in quenching temperatures for the alloys of the 0.5-percent carbon type and to the low range when the carbon content was about 0.7 percent. Apparently this improvement is a secondary effect, possibly due to a change in the grain size at the austenitizing temperatures.

The relation of critical cooling rate to austenite grain size of the iron-carbon alloys is given in figure 12. The general trend was for the hardenability of the alloys, without and with boron, to increase (critical cooling rate decreased) as the size of the austenite grains increased. The critical cooling rate of the 0.74 -percent carbon-0.0028percent boron alloy ranged from about $500^{\circ}$ to $900^{\circ} \mathrm{F}$ per second without an appreciable change in austenite grain size.

To determine the primary effect of boron on hardenability, a comparison should be made of the critical cooling rate of alloys of the same carbon content, without and with boron, when quenched from temperatures sufficiently high to ensure complete solution and uniform distribution of carbon in austenite of the same grain size. Unfortunately, in the present experiments these conditions were not met for wide ranges in both carbon content and size of the austenite grains. However, the data obtained from figure 12 permit such a comparison to be made of the alloys with austenite grain sizes of about 10 and 5 grains/in. ${ }^{2}$ at 100 diameters (ASTM No. 4 and 3). When the critical cooling rate is plotted against the carbon content of the alloys each with the same austenite grain size (10 or 5 grains/in. ${ }^{2}$ at $\left.\times 100\right)$, no significant improvement is shown in the hardenability due to boron (fig. 13).

It is noteworthy that a change in austenite grain size of about one ASTM number of a given boron-free alloy initially as homogenized had considerably more effect on its hardenability than the addition of about 0.002 percent boron, provided the austenite grain size was not changed.

Specimens initially as cast. The hardenability 
of high-purity-iron-carbon-boron alloys may be affected by hot-working, or thermal treatments carried out during the course of their preparation. Tests, therefore, were made on specimens prepared from boron-treated ingots (as cast) containing 0.32 , 0.47 , and 0.74 percent of carbon, respectively (B6, B2, and B5) and on a boron-free alloy with 0.50 percent of carbon (B7). The effect of the initial structural condition on the hardenability of the 0.50-percent carbon alloy without boron was not marked; slightly higher critical cooling rates were required with initially cast than with homogenized specimens when the quenching temperature was within the range of about $1,500^{\circ}$ to $1,600^{\circ} \mathrm{F}$ and lower rates in the former specimens when quenched from $2,000^{\circ} \mathrm{F}$.

The relation of cooling time to structure of specimens, initially as cast, of the 0.32 -percent carbon-0.0021-percent boron alloy when quenched from different temperatures is given in figure 14 . The curves show the relation of critical cooling time to quenching temperature. More consistent results were obtained with these specimens than with those prepared from the homogenized bar of the same alloy (fig. 5).

The relation of critical cooling rate to quenching temperature of some of the alloys initially as cast (curves A) and initially as homogenized (curves B) is summarized in figure 15 . With an initial structure as cast, the hardenability was markedly improved by the addition of boron to alloys containing 0.32 - or 0.47 -percent carbon, but the presence of boron in the 0.74 -percent carbon alloy again had no material effect on the critical cooling rate. The lower hardenability of the initially cast specimens of the 0.74 -percent carbon alloy when quenched from $1,425^{\circ}$ or $1,500^{\circ} \mathrm{F}$ was due to incomplete solution and nonuniform distribution of carbon in austenite at these temperatures, as evidenced by the presence of free carbides after quenching. As previously stated, the initially homogenized specimens of the 0.32-percent carbon-0.0021-percent boron showed nonuniform hardening characteristics. Because of this condition, it was necessary to use the results obtained with initially homogenized specimens of the alloy without boron as a basis for evaluating the effect of initial structure on the hardenability of the boron-treated alloy containing 0.32-percent carbon. Considerably higher cooling rates were required to completely harden the 0.32 - and 0.47 - percent carbon alloys in the initial condition as homogenized than as cast when quenched from alike temperatures within the range of $1,500^{\circ}$ or $1,600^{\circ}$ to $2,000^{\circ} \mathrm{F}$.

The observed difference in hardenability cannot be ascribed to a grain-size effect, as the sizes of the grains established at the austenitizing temperatures for 0.47 -percent carbon 0.0020 -percent boron alloy were nearly alike in the two series of specimens, and the average size of the austenite grains obtained at each austenitizing temperature of the 0.32-percent carbon-0.0021-percent boron alloy was slightly finer in the initial condition as cast than as homogenized (table 2). As boron improved the hardenability of the two alloys $(0.3$ and $0.5 \%$ carbon) in the initial condition as cast but was practically without effect after hot-working and homogenizing, it is clearly apparent that the action of boron on hardenability was adversely affected during the course of these treatments, probably by the exposure to the relatively high temperature required for forging. In carrying out the forging operation, the ingots ( 1 to $1 \frac{1}{2}$ in. in diameter) were placed in a furnace within the temperature range of $1,900^{\circ}$ to $2,100^{\circ} \mathrm{F}$, in a reducing atmosphere, held in the furnace for $3 / 4$ to $1 \mathrm{hr}$ and then forged, without reheating, with a drop hammer to approximately $1 / 2 \mathrm{in}$. in diameter; forging was completed at a temperature above $\mathrm{Ar}_{3}$, and the forged bars were cooled in air. Microscopic examination of cross sections of the forged bars showed the presence of a decarburized layer at the surface of the 0.47 -percent carbon alloy (B2) and no appreciable decarburization of the 0.32-percent carbon alloy (B6). The usual procedures as previously described were followed in removing the outer surfaces from the forged bars and in carrying out the homogenizing treatments.

There was no pick-up in the amounts of nitrogen or oxygen during the forging and homogenizing operation as shown by the results of analysis by the vacuum fusion method on specimens of the 0.32 -percent carbon alloy (B6). The results of determinations for boron by chemical analysis on bars as forged (B2) or as homogenized (B6) showed the presence of sufficient boron $(0.002 \%$, table 1$)$ to enhance the hardenability of each alloy.

Grange and Garvey [4] also found that when a boron-treated steel is heated at a very high temperature for a very long time, the increase in 
hardenability due to boron gradually diminishes and finally disappears, although the boron content as measured by analysis remains unchanged. They express the opinion that possibly part or all of the efficacy of boron in enhancing hardenability is lost when the steel is heated for rolling or forging.

The results summarized in figure 15 for initially cast specimens also show that the boron-treated alloys containing 0.32-percent and 0.47-percent carbon had critical cooling rates of the same order of 'magnitude when austenitized alike, and these rates were, in all cases, slower than those of the boron-treated alloy containing 0.74-percent carbon; in hypoeutectoid plain-carbon steels, the hardenability increases with an increase in carbon content, provided all other factors that affect hardenability are alike. Thus the action of boron on the hardenability of these high-purity alloys, as cast, varied with their carbon content; the effectiveness decreased with an increase in carbon, the improvement being very pronounced with 0.3 -percent, intermediate with 0.5 -percent, and nil with 0.74-percent carbon. Rahrer and Armstrong [21] and Grange and Garvey [4] also reported the above trends with commercial steels.

The hardenability of certain commercial borontreated [4] and experimental [1] steels decreased with an increase in quenching temperature. It is interesting, however, to note from the results given in figure 15 , that the hardenability of these boron-treated alloys did not decrease with an increase in quenching temperature.

\section{(b) Iron-Carbon-Manganese Alloys}

Critical Cooling Rate. The relation of cooling time to structure of the iron-carbon-manganese alloys, without and with 0.0024-percent boron, when quenched from various temperatures, is shown in figures 16 and 17 , respectively, and the relation of critical cooling rate to quenching temperature is given in figure 19. Variation in quenching temperature from $1,500^{\circ}$ to $2,000^{\circ} \mathrm{F}$ had no material effect on the critical cooling rate (fig. 19) or average size of the austenite grains (table 2) of the alloy without boron (B13), whereas with the boron-treated alloy (B14) the trend was for the hardenability to increase slightly with temperature and for the grain size to increase with a change in temperature from $1,600^{\circ}$ to $2,000^{\circ} \mathrm{F}$.
End-Quench Test. The curves obtained from the results of the end-quench test of the ironcarbon-manganese alloys are given in figure 18, and the relation of quenching temperature to the distances from the quenched end of the bar corresponding to Rockwell hardness values of $\mathrm{C} 42$ (50\% martensite) and C50 (95\% martensite) is shown in figure 19.

When a comparison is made on the basis of the distances from the quenched end for Rockwell values of C42 or C50 (fig. 19), the hardenability of each alloy was increased slightly by a change in quenching temperature from $1,500^{\circ}$ to $1,700^{\circ} \mathrm{F}$, but there was no further improvement by increasing the temperature to $1,900^{\circ} \mathrm{F}$. The observed improvement in hardenability with a change in quenching temperature from $1,500^{\circ}$ to $1,700^{\circ}$ may be due to a grain size effect.

The effect of boron on the hardenability of the iron-carbon-manganese alloys as determined by critical cooling rate and by the end-quench tests is also shown by the results summarized in figure 19. For each austenitizing temperature used, the hardenability was enhanced by the presence of boron. This improvement appears to be a primary rather than a secondary effect, as the differences in grain size of the alloys at each temperature is insufficient to account for the magnitude of the observed effects. For example, the specimens of both alloys used for determining the critical cooling rate had approximately the same grain size at $1,500^{\circ}$ and $1,600^{\circ} \mathrm{F}$, but the hardenability of the alloy containing boron was considerably higher than that of the alloy without boron; a part of the observed increase in hardenability of the boron-treated alloy when quenched from within the temperature range of about $1,700^{\circ}$ to $2,000^{\circ} \mathrm{F}$ may be due to its larger grains (table 2 ).

The increase in hardenability of the iron-carbonmanganese alloys by the addition of boron was considerably more marked when measured in terms of the critical cooling rate than by the endquench test.

\section{(c) Commercial Steels}

End-Quench Test. It was shown previously [1] that the hardenability as determined in the endquench test of certain boron-treated experimental and commercial steels was affected by the quenching temperature. In some of the steels, the hardenability was increased by increasing the quench- 
ing temperature above the usual recommended range; whereas in other steels the hardenability was not affected, or was decreased by this change. With specimens initially normalized from the usual recommended temperature range, it was shown [1] that variations in quenching temperature from $1,550^{\circ}$ to $1,900^{\circ} \mathrm{F}$ had no material effect on the hardenability of boron-treated steels (table 1) C14 $(0.0036 \% \mathrm{~B})$, and $\mathrm{C} 19(0.0001 \% \mathrm{~B})$; the hardenability of the base steel C15 (without boron) increased slightly by increasing the quenching temperature from $1,550^{\circ}$ to $1,900^{\circ} \mathrm{F}$, but the hardenability of another boron-treated steel C12 $(0.0022 \%$ B) was decreased somewhat by increasing the quenching temperature from about $1,550^{\circ}$ or $1,650^{\circ}$ to $1,900^{\circ} \mathrm{F}$. Several of these commercial open hearth steels (table 1), all prepared from the same heat, were selected for use in a further study of the factors, such as variations in initial structure, austenite grain size, etc., that might influence the hardenability.

The results of some of the end-quench tests made on the commercial steels containing 0.43percent carbon, 1.6-perecnt manganese, and varying amounts of boron are summarized in figure 20 .

The influence of boron on the hardenability of these steels when normalized and quenched from the usually recommended temperatures is shown by the relative position of the curves in figure 20A. The hardenability of each steel (C9, C12, C14, and C19) was markedly improved by boron, but the retention of 0.0001 percent was nearly as effective as retaining 0.0036 percent. As these results were obtained on specimens that were normalized and end-quenched from recommended temperatures, the curves are used as a basis for correlating the hardenability of the steels after various thermal treatments.

A change in normalizing temperature from $1,650^{\circ}$ to $1,900^{\circ} \mathrm{F}$ followed by end-quenching from $1,550^{\circ} \mathrm{F}$ did not appreciably affect the hardenability of the base steel (C15), or borontreated steels C9, C14, (fig. 20, B) and C12, but the hardenability of steel C19 with 0.0001-percent retained boron was decreased slightly by this change. The hardenability of these steels was not significantly affected by quenching from $1,900^{\circ} \mathrm{F}$ in water prior to end-quenching from $1,550^{\circ} \mathrm{F}$, as is illustrated for steels $\mathrm{C} 15, \mathrm{C} 9$, and C19 in figure 20, C (C14 not included in the test). That steel C19 is sensitive to prior thermal treat- ment is clearly shown by the results summarized in figure 20, D, E, and F. Its hardenability was of the same order of magnitude as the base steel when the specimens were treated alike by heating to $1,900^{\circ} \mathrm{F}$ followed by cooling in another furnace at either $1,550^{\circ}$ or $1,425^{\circ} \mathrm{F}$ for $30 \mathrm{~min}$ before end-quenching (fig. 20, D and E). However, the hardenability of the steels with higher boron content was not appreciably affected by these treatments (steel C12, fig. 20, D and steels C9 and C14, fig. 20, E). Furthermore, the hardenability of steels $\mathrm{C} 9$ and $\mathrm{C} 14$ was not changed by increasing the time of holding at $1,425^{\circ} \mathrm{F}$ from $1 / 2$ to $5 \mathrm{hr}$. before end-quenching. The slight improvement in the hardenability of the base steel (compare curves of steel C15, fig. 20, A and E) was probably due to an increase in grain size with the higher austentizing temperature $\left(1,550^{\circ}\right.$ and $1,900^{\circ} \mathrm{F}$, respectively). The hardenability of boron-treated steel C19 was also impaired by an initial treatment that consisted of heating to $1,900^{\circ} \mathrm{F}$, cooling in another furnace at $1,425^{\circ} \mathrm{F}$ for $30 \mathrm{~min}$, and then quenching in water before cnd-quenching from $1,550^{\circ} \mathrm{F}$ (fig. 20, F). The hardenability thus impaired (specimen C19 A), however, was restored to approximately its normal value by increasing the temperature of the endquench test from $1,550^{\circ}$ to $1,750^{\circ} \mathrm{F}$ (specimen C19 B).

\section{Effect of Quenching Temperature on Ar" Transformation}

Many of the photographic records obtained during the continuous cooling of small specimens by quenching directly from various austenitizing temperatures showed an arrest in the cooling curve in the temperature range of martensite formation. The clarity of the arrest as shown in the photographs and from a plot of the time-temperature cooling curve varied with the carbon content of the alloys and with the rate of cooling. A summary of the data from these photographic records indicated a very definite trend for the temperature of the start of the transformation of austenite to martensite (start of the $\mathrm{Ar}^{\prime \prime}$ or $\mathrm{Ms}$ ) in the highpurity alloys to increase with increase in quenching temperature. Because of this unexpected relation, attempts were made to obtain the $\mathrm{Ms}$ point in several of the alloys (B2, B7, B13, and B14) by a quench-temper technique as described and used by Greninger and Troiano [22]. These alloys, 
however, are relatively shallow hardening, and the Ms point was not accurately determined by this method. A deeper-hardening commercial steel (C14) was, therefore, selected for determining, both by thermal analysis and by the metallographic method, the influence of quenching temperature on the temperature of the Ms point.

Specimens of steel C14 were quenched directly from the austenitizing temperatures and the temperatures of the start of the formation of martensite were obtained from the photographic records in the usual manner. The procedures as already described for preparing small specimens, heating, quenching, and recording the cooling curves, were also followed in carrying out these tests. The average value as determined from cooling curves on two to four specimens quenched from each of the selected temperatures are given in figure 21 . Again the trend was for the temperature of Ms to increase with increase in quenching temperature. However, additional tests on specimens that were austenitized at either $1,900^{\circ}$ or $2,000^{\circ} \mathrm{F}$ and then cooled and held in the temperature range of $1,500^{\circ}$ to $1,600^{\circ} \mathrm{F}$ before quenching, showed values for the Ms temperature that were only slightly higher than those obtained in austenitizing and quenching directly from the lower temperatures. Other specimens that were austenitized at $2,000^{\circ} \mathrm{F}$ and then cooled, without decomposing the austenite, to a temperature within the range of about $1,100^{\circ}$ to $900^{\circ} \mathrm{F}$ before quenching, gave an average value for the Ms point that was about the same as that obtained on quenching directly from $1,600^{\circ} \mathrm{F}$. Furthermore, the results of determinations by the metallographic method show no appreciable difference in the temperature of the Ms point with quenching temperatures of $1,600^{\circ}, 1,800^{\circ}$, and $2,000^{\circ} \mathrm{F}$. The observed increase in the Ms temperature with increase in quenching temperature is apparently due to the method of thermal analysis and is probably not a characteristic of the alloys.

The average size of the austenite grains in specimens of steel C14 ranged from about ASTM grain number 5 to 2 with change in temperature from $1,550^{\circ}$ or $1,600^{\circ}$ to $2,000^{\circ} \mathrm{F}$. This range in grain size had no significant effect on the temperature of the start of the formation of martensite as determined by the metallographic method.

\section{Diffusion of Boron in Austenite of Commercial Steels}

The penetration of boron in low-carbon steel has been investigated by Tschischewsky [23] and by Campbell and Fay [24]. According to Campbell and Fay, the boron and carbon steels show many similarities in the mechanism of their absorption and diffusion phenomena. In the absence of nitrogen, they found that the penetration of boron followed a normal diffusion curve but when a boron-treated specimen was heated at $900^{\circ} \mathrm{C}$ in ammonia, the nitrogen displaced the boron at its surface. They concluded that at $900^{\circ} \mathrm{C}$ boron had a greater affinity for nitrogen than it had for iron.

Specimens of three of the commercial borontreated steels (C11, C12, and C14, table 1) were decarburized by heating in a reducing atmosphere (mixture of natural and manufactured gas with air, moisture not removed) at $1,550^{\circ}$ or $1,900^{\circ} \mathrm{F}$ for $8 \mathrm{hr}$ and then cooled in mica. The depth of decarburization was estimated metallographically, and the boron content in the decarburized layer was determined spectrographically. The results obtained are summarized in table 3 and illustrated in figure 22. The depth of the decarburized layer of a specimen of steel C14 decarburized at $1,900^{\circ} \mathrm{F}$ is shown by the structure reproduced in the photomicrograph at the top of figure 22, and the heavy horizontal line represents the nominal boron content $(0.0038 \%)$ as determined spectrographically. There was a high concentration of boron at the original surface of the specimens, which probably was due to a reaction of the diffusing boron with oxygen in the furnace atmosphere to form boron oxide $\left(\mathrm{B}_{2} \mathrm{O}_{3}\right)$; the specimens were colored dark during the decarburizing treatment. The boron content slightly below the original surface (about 0.003 in. for specimens of C14, fig. 22) was usually less than the value that could be accurately determined by the methods employed (limits of sensitivity were about 0.0002 and $0.0005 \%$ boron). A concentration gradient extended from this zone where the boron was practically depleted to a depth usually as great or greater than the severely decarburized layer. The approximate value of the coefficient of diffusion of boron (D) as computed from experimental results obtained with this 
specimen ${ }^{2}$ also indicated that the rate of diffusion of boron in gamma iron was of the same order of magnitude as that of carbon. Thus the rate of diffusion of boron in austenite at $1,550^{\circ}$ or $1,900^{\circ} \mathrm{F}$ appears to be equivalent to or slightly greater than that of carbon in steels containing 0.4 percent of carbon. It is therefore logical to assume that the mechanism of the diffusion process for boron in austenite is quite similar to that of carbon. That is, the boron atoms are located in the interstices of the gamma iron lattice.

\section{Structures of the Alloys and Steels}

A metallographic examination was made of the high-purity alloys used to evaluate hardenability in the conditions as cast, forged, and homogenized. The examination was extended to include specimens specially heat-treated to develop a constituent containing boron in each of the borontreated alloys and steels listed in table 1 . Some of the specimens containing a boron constituent were examined with an electron microscope.

\section{Initially as Cast and as Homogenized}

Numerous particles in the form of spheroids and stringers were observed in the structures of the boron-treated alloys containing $0.3-, 0.5$-, and 0.7 percent carbon in the conditions as cast and as homogenized, as is illustrated in the photomicrographs of figure 23. The trend was for the particles to form in the ferritic areas especially when the proeutectoid ferrite was located in the parent austenite grain boundaries. These particles appear to be carbides, some of which are complex (fig. 23, E), as is indicated by their reaction to a picral or nital etch (differentially attacked, fig. 23, E, not appreciably attacked, fig. 23, A, B, and C) and to an electrolytic etch in a sodium cyanide solution (attacked, fig. 23, F). The results of micro hardness measurements using the Knoop instrument with a 25 -g load also indicated that the particles were harder than the ferrite matrix. The carbide particles also were observed in the primary austenite grain boundaries of polished

2 The authors are indebted to Cyril Wells, Carnegie Institute of Technology, for computing and reporting the approximate value of the rate of diffusion of boron in this specimen (at $1,900^{\circ} \mathrm{F}, D=2.0 \times 10^{-7} \mathrm{~cm}^{2} / \mathrm{sec}$ ). Additional and considerably more precise tests to determine the rate of diffusion of boron in high-purity iron-carbon alloys containing 0.32 percent of carbon (B6 and B8) and in experimental and commercial steels under varying conditions are now in progress in that laboratory. The results will be published at a later date by Wells.
TABLE 3.-Boron content of decarburized layer of commercial boron-treated steels

The limits of sensitivity of the spectrographic methods were 0.0002 -percent for the low, and 0.0005-percent boron for the high concentrations. These determinations were confined to layers 0.004 and 0.002 in. immediately below the surfaces, respectively. Each value for boron given in the table is the result of a single determination, and the depth is that of the surface at which the are was struck, not the depth to which the pit due to the arc extended.

The specimens were ground to the desired depths with boron-free wheels.

\begin{tabular}{|c|c|c|c|}
\hline \multirow{2}{*}{ Depth 1} & \multicolumn{3}{|c|}{ Boron-content of specimen- } \\
\hline & $\mathrm{C} 11$ & $\mathrm{C} 12$ & $\mathrm{C} 14$ \\
\hline \multicolumn{4}{|c|}{ Decarburized 0.025 to 0.04 in. ${ }^{2}$} \\
\hline in. & $\%$ & $\%$ & $\%$ \\
\hline 0.000 & 0.030 & 0.029 & 0.051 \\
\hline .001 & .046 & .017 & .022 \\
\hline .002 & $<.0005$ & .0012 & $<.0005$ \\
\hline .003 & $<.0002$ & $<.0002$ & $<.0002$ \\
\hline .003 & $<.0002$ & $<.0002$ & $<.0002$ \\
\hline .011 & $<.0005$ & $<.0005$ & $<.0005$ \\
\hline .012 & $<.0005$ & $<.0005$ & $<.0005$ \\
\hline .022 & $<.0005$ & $<.0005$ & .0023 \\
\hline .022 & $<.0005$ & $<.0005$ & .0023 \\
\hline .031 & $<.0005$ & $<.0005$ & .0026 \\
\hline .032 & $<.0005$ & $<.0005$ & .0028 \\
\hline .041 & $<.0005$ & $<.0005$ & .0027 \\
\hline .042 & .0005 & .0006 & .0031 \\
\hline .051 & .0006 & .0007 & .0034 \\
\hline .051 & .0007 & .0013 & .0030 \\
\hline .054 & $<.0005$ & .0011 & .0027 \\
\hline .060 & .0006 & .0007 & .0031 \\
\hline .063 & .0005 & .0007 & .0032 \\
\hline .064 & .0007 & .0013 & .0033 \\
\hline .077 & .0008 & .0021 & .0036 \\
\hline .077 & .0010 & .0022 & .0037 \\
\hline .090 & .0010 & .0021 & .0038 \\
\hline \multicolumn{4}{|c|}{ Decarburized 0.01 to 0.02 in. $^{3}$} \\
\hline 0.000 & 0.023 & 0.013 & 0.022 \\
\hline .001 & $<.0005$ & .0035 & .0025 \\
\hline .001 & - & .0041 & .010 \\
\hline .003 & $<.0002$ & .00055 & .0021 \\
\hline .003 & $<.0002$ & .00035 & .0017 \\
\hline
\end{tabular}

1 Distance from the surface of the specimen as decarburized. These surfaces were ground prior to decarburizing.

2 The specimens were decarburized by heating at $1,900^{\circ} \mathrm{F}$ in a reducing atmosphere for $8 \mathrm{hr}$, followed by cooling in mica.

3 The specimens were decarburized by heating at $1,550^{\circ} \mathrm{F}$ in a reducing atmosphere for $8 \mathrm{hr}$, followed by cooling in mica.

but unetched specimens of the 0.47 -percent carbon-0.0020-percent boron alloy as cast (B2, fig. $23, \mathrm{D})$. Since the free carbide particles were observed principally in the high-purity alloys containing boron, it is logical to believe that most of these particles are cementite containing boron. 
The structure of the alloys as cast and as homogenized consisted of proeutectoid ferrite, pearlite varying somewhat in degree of fineness, and spheroided carbides (fig. 23, A, B, C, E, and F). Obviously, the relative amounts of ferrite and pearlite varied with the carbon content.

\section{Heat Treatments to Develop a Boron Constituent}

Grange and Garvey [4] described a metallographic test for determining the presence of boron in steel, and they attempted to correlate the observed amounts of a constituent in specially treated specimens with the actual boron content and hardenability. Essentially, the test consists of austenitizing small specimens (about $1 / 8 \mathrm{in}$. thick) at a high temperature $\left(2,000^{\circ}\right.$ to $2,100^{\circ} \mathrm{F}$ for $10 \mathrm{~min}$.) followed by cooling rapidly in a lead or salt bath at $1,200^{\circ} \mathrm{F}$ (temperature of this bath may be changed to suit existing conditions), holding at this temperature for a sufficient time to allow the constituent to precipitate, and finally cooling to room temperature preferably by quenching in water or brine. The original surface layer of the heat-treated specimen is removed preparatory to polishing and then etching in picral for metallographic examination at a magnification of approximately 500 diameters. They found that the constituent (dark-etching dots) always formed as a partial or continuous network in the parent austenite grain boundaries of the specially treated specimens of steels containing a minimum of 0.0004-percent boron. The hardenability of their steels correlated somewhat better with the amount of boron constituent than with the actual boron content, but they concluded that the hardenability of boron-treated steels can be safely estimated only from the results of a hardenability test. The precise nature of the constituent was not known, but to the authors it appeared to be an iron boride probably containing carbon and other alloying elements.

A boron constituent was observed in specially treated specimens of the boron containing alloys and steels listed in table 1 ; only very small amounts were observed in a commercial steel with $0.0001-$ percent boron (C19) and possibly a trace in carburized specimens of iron-boron alloy (B13) initially with relatively high oxygen content. Some of these specimens were heat-treated according to the procedure recommended by Grange and Garvey, but other specimens heat-treated quite differently frequently contained this constituent. The results are illustrated in figures 24, 25, and 26.

The tendency for the carbides to spheroidize in high-purity iron-carbon-boron alloys is further illustrated in the photomicrographs of figure 24 . Although this specimen, in cooling from $1,900^{\circ} \mathrm{F}$ was held for only $1 \mathrm{~min}$ in the temperature range where pearlite is formed, the final structure indicates that the time was ample for some spheroidization of the carbides to occur in a coarse pearlite area; the spheroids as shown extending linearly across the photomicrographs in figure $24, \mathrm{~A}$ and $\mathrm{B}$, were attacked by etching electrolytically in a sodium cyanide solution. The dark etching dots (believed to be a boron constituent) in the martensite areas (fig. 24, C) are considerably smaller than the carbides located in the ferritic area. Additional study is needed to identify positively the former particles. It is of interest to note the continuity in the alinement of both size particles in the form of a partial network located in the prior austenite grain boundaries.

The trend was for the boron constituent to be concentrated in the parent ausenite grain boundaries of the specially treated specimens of the alloys and steels (fig. 25, A and B). However, some dark etching particles often were observed within the grains of these and of other specimens that were cooled rapidly, directly from high austenitizing temperatures, as is illustrated in figure 25, $\mathrm{C}$ and $\mathrm{D}$. The result obtained on a small specimen of a commercial steel (C14) that was austenitized at $2,000^{\circ} \mathrm{F}$ and quenched into iced sodium hydroxide solution (fig. 25, C and D) indicates either that all of the boron $(0.0036 \%)$ was not in solution in the austenite at $2,000^{\circ} \mathrm{F}$ or that the formations of the precipitate cannot be entirely suppressed by extremely rapid cooling from this temperature. The constituent also was observed in other specimens of this steel that were cooled from the austenitizing temperature $\left(2,000^{\circ}\right.$ F) in air or in oil.

Many of the data indicated that the solubility of boron in gamma iron decreased with an increase in temperature but, in a few cases, the results also indicated that the solubility increased with the temperature.

The number, size, and distribution of the boroncontaining particles varied with the amount and form of boron and with the conditions used in heat treating the specimens, including austenitiz- 
ing temperature and atmosphere, rate of cooling, temperature of quenching bath, and time held in the bath if at elevated temperature, and temperature of reheating.

Furthermore, the success in revealing the presence of the boron constituent in these specimens varied appreciably from time to time, with the polishing and etching technique, as is illustrated in figure 25, C and D. Although a similar procedure for preparing this specimen was followed on two occasions by different persons, it is apparent that considerably more of the "dots" are shown within the parent austenite grains in figure $25, \mathrm{D}$, than in figure $25, \mathrm{C}$.

The boron constituent was observed in a specimen of a high-purity iron-boron alloy with less than 0.01-percent carbon that was heated to $2,000^{\circ} \mathrm{F}$ and then cooled in a lead bath at $1,700^{\circ}$ $\mathrm{F}$ (gamma field) for $5 \mathrm{~min}$ and finally quenched in sodium hydroxide solution at room temperature (fig. 26, A). The dark etching constituent delineated the gamma (austenite) grains, and it also precipitated within the grains on parallel planes thus giving the appearance of twinning. Although no appreciable decarburization could occur during the austenitizing of this specimen (less than $0.01 \%$ carbon) the boron constituent did not extend to its original surface; the left edge of the photomicrograph in figure 26, A, corresponds to the surface of the quenched specimen. Some, but not all, of the constituent was dissolved on reheating this specimen in lead at $1,650^{\circ} \mathrm{F}$ for $5 \mathrm{~min}$; compare the amount of the constituent as shown in the photomicrograph of figure 26, C, with that of $\mathrm{A}$ and note in $\mathrm{C}$ that the ferrite grain boundaries appear to be located independently of the network.

If it is assumed that all the oxygen in this B4 alloy $(0.008 \%$ by vacuum fusion analysis) reacts with the boron to form a boron oxide of the composition $\mathrm{B}_{2} \mathrm{O}_{3}$, sufficient boron would still be available to produce the observed constituent. However, in another alloy (B3), which contained 0.011percent oxygen and 0.0028-percent boron, there is not sufficient boron to react with all the oxygen to form this compound. Specimens of the latter alloy were subjected to various heat treatments, as summarized in table 4, preparatory to carrying out the metallographic examination in the usual manner. No boron constituent was observed in any of these specimens, thus indicating that the constituent is not an oxide of the metal boron.
However, what might be traces of the constituent were observed in the carburized zone of specimens of this alloy that were pack carburized prior to the special treatment (designated as 9 in table 4).

TABLE 4. Heat treatment of specimens of iron-boron alloy (B3 <0.01 percent carbon, 0.0028 percent boron) to develop a boron constituent

\begin{tabular}{|c|c|c|c|c|}
\hline \multirow{3}{*}{ Designation of treatment } & \multicolumn{4}{|c|}{ Heat treatment 1} \\
\hline & \multicolumn{2}{|c|}{ Furnace } & \multicolumn{2}{|c|}{ Lead bath } \\
\hline & $\begin{array}{l}\text { Tempera- } \\
\text { ture }\end{array}$ & Time & $\begin{array}{l}\text { Tempera- } \\
\text { ture }\end{array}$ & Time \\
\hline $1 \ldots$ & $\begin{array}{c}{ }^{\circ} \mathrm{F} . \\
2,300\end{array}$ & $\underset{2}{\min }$. & ${ }^{\circ} F$ & $\min$. \\
\hline $2 \ldots \ldots$ & 2,000 & 3 & - n. & ...... \\
\hline $3 \ldots \ldots$ & 2,000 & 7 & - & 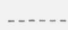 \\
\hline $4 \ldots \ldots$ & 2,000 & 3 & 1,200 & 2 \\
\hline 5 & 2,000 & 3 & 1,200 & 5 \\
\hline 6 & 2,000 & 3 & 1,300 & 1 \\
\hline $7 \ldots$ & 2,000 & 3 & 1,500 & 2 \\
\hline 8 & 2,000 & 3 & 1,600 & 5 \\
\hline 9 & 2,000 & 3 & 1,700 & 5 \\
\hline
\end{tabular}

1 The procedure was to place the specimen in the furnace at temperature for the time as indicated and then either quench directly into sodium hydroxide at room temperature (treatments 1, 2, and 3) or transfer to a lead bath at temperature for time as indicated before quenching in sodium hydroxide at room temperature. A reducing atmosphere (graphite crucible containing powdered charcoal) was used in the furnace for carrying out treatments $3,4,5$, and 6 , and an oxidizing atmosphere (air) for the other treatments.

It should be pointed out that the particles composing the chain-like constituent appear, at high magnification, to be similar to inclusions, as is illustrated in figure 26, B. Possibly the constituent was dissolved by the acid (picric) or was removed by polishing and the two oval or round spots (fig. 26, B) are voids in the specimen. A preliminary examination of this and several other specimens with the electron microscope was unsuccessful in determining if these "dots" are merely voids. An attempt to measure the hardness of the boron constituent by means of microhardness tests (Knoop instrument or Tukon Tester) also was unsuccessful.

The ease with which this constituent was formed and observed in specimens of the highpurity alloys varied with the initial structural conditions. Usually, the constituent was considerably more pronounced in specially treated specimens prepared from the as-cast ingots than from homogenized bars. In some of the latter specimens it was recognized metallographically with certainty only in an occasional field, but it 
was never observed in severely decarburized portions of any of the specimens from the alloys and steels (fig. 26, A).

Specimens prepared from various experimental high-nitrogen steels described in a previous report [1] were subjected to different treatments to develop the boron constituent. The constituent was not observed in the specimens containing high-soluble nitrogen (0.01 to $0.03 \%$ soluble in sulfuric acid), whereas it was readily produced in specimens of steels containing similar amounts of nitrogen that were treated with titanium to fix the nitrogen as titanium nitride. Thus the boron constituent is not a nitride. Presumably compounds of boron and oxygen or boron and nitrogen existed in specimens of the high-oxygen alloys or high-soluble nitrogen steels containing boron in which the chain-like constituent was not developed. It should be pointed out that such compounds were not identified in these specimens as polished and unetched or as etched. The boron constituent developed in these tests therefore, was not an oxide or a nitride, and it does not appear to be a carbide. Its exact identification is not established, but it is believed to be an iron boride.

Attempts were made to correlate the boron constituent, as observed in specially heated specimens with the hardenability of the high-purity alloys and some of the experimental high-nitrogen steels. As previously stated, the boron constituent was observed in specimens prepared from the ingots and from homogenized bars of the boron-treated alloys containing $0.32,0.47$, and 0.74 percent of carbon, but in some of the initially homogenized specimens the amount of the constituent was considerably less than that of specimens from the ingots. The hardenability of all the initially homogenized alloys and of the 0.74-percent-carbon alloys as cast was not materially enhanced by boron. With the high-nitrogen steels the hardenability as determined in the end-quench test was not significantly improved by the addition of boron and no boron constituent was observed in the metallographic test when the soluble nitrogen was relatively high whereas the hardenability was increased by boron. and the constituent was observed when the nitrogen was fixed with titanium.

It is clear, therefore, that the presence or absence of the boron constituent as determined by the metallographic test often indicates the response in hardenability of the steel to a boron treatment but it is not always a reliable criterion of this effect.

\section{Mechanism of Boron Effect on Hardenability}

A summary of the present results and those published previously strongly supports the belief of the authors that the effectiveness of boron in enhancing the hardenability of certain steels is due entirely to its action while in solid solution in austenite. Only the portion of the boron that is in solution at the time of quenching contributes toward an increase in hardenability. The boron undissolved or in the form of compounds is either without effect, or possibly decreases hardenability by acting as transformation centers for austenite in the temperature range where pearlite is formed.

In addition to dissolving in austenite, boron can exist in steel in the form of compounds with nitro gen, oxygen, iron, and carbon. Some of these compounds are stable and are not decomposed at temperatures ordinarily used in the heat treatment of boron-treated steels, whereas other compounds containing boron may be partially or entirely decomposed at these temperatures. Some data indicate an increase in solubility of boron in gamma iron with increasing temperature, whereas other results indicate a decrease in solubility with increasing temperature in this field. In any event, only a very small amount of boron is retained in solution at heat-treating temperatures, and it is possible to obtain the maximum response in the hardenability of certain steels by relatively minute additions of this element.

With steels, isothermally transformed, it was shown [19] that the addition of boron did not decrease the rate of formation of pearlite in the temperature range just below $\mathrm{Ae}_{1}$ (coarse pearlite), but boron had a marked effect in retarding the rate of formation of pearlite in the temperature range corresponding to the nose of the S-curve (fine pearlite). Pearlite is formed by a process of nucleation and growth. It has also been shown [25] that the rate of growth is the governing factor in the rate of formation of coarse pearlite, whereas the rate of nucleation is the controlling factor in the rate of formation of fine pearlite. When boron enhances the hardenability of a steel, therefore, it decreases the rate of nucleation and not the 
rate of growth of ferrite and carbide. The boron atom, believed to be located interstitially in the gamma iron lattice, is effective in retarding either the rate of formation of nuclei or the rate of their growth to the critical size necessary for transformation to begin, or both.

\section{Summary}

A series of high-purity iron-carbon alloys varying in carbon content and other high-purity alloys containing 0.4 percent of carbon and 0.7 percent of manganese were prepared for use in this investigation. Several steels from a commercial openhearth heat also were included in the testing program. The hardenability of the iron-carbon alloys as affected by variations in initial structural conditions and in quenching temperature and of the iron-carbon-manganese alloys as affected by variations in quenching temperature was determined in terms of the critical cooling rate. In addition, the end-quench test was used for determining the hardenability of the iron-carbonmanganese alloys in some of the experiments carried out with the commercial steels. Wide use was made of the metallographic test described by Grange and Garvey [4] for detecting the presence of boron in the form of a constituent in specially treated specimens of the high-purity alloys, commercial steels, and other experimental steels containing high nitrogen.

The addition of 0.002 percent of boron had no material effect on the austenite grain size or grain coarsening temperatures of the high-purity alloys. As these alloys were not deoxidized, except with carbon and in one alloy by some aluminum picked up from the crucible, the test specimens contained intermediate or coarse grains at relatively low austenitizing temperatures.

The general trend in the high-purity alloys, without and with boron, was for the critical cooling rate to decrease (hardenability increase) as the size of the austenite grains increased.

The influence of boron on the hardenability of the iron-carbon alloys varied with the initial condition of the alloys and with the carbon content. The hardenability of the alloys containing $0.3,0.5$, and 0.75 percent of carbon initially as forged and homogenized and the 0.75 -percentcarbon alloy as cast was not significantly affected by the addition of boron. However, the hardenability of the ingots (as cast) containing 0.3 and
0.5 percent of carbon was markedly improved by the boron. Each of these two ingots showed approximately the same degree of hardenability, and they were somewhat deeper hardening than the boron-treated 0.75-percent-carbon alloy.

The hardenability of initially forged and homogenized iron-carbon-manganese alloy was enhanced by the presence of boron.

Evidence was obtained that the response in hardenability of a commercial steel containing 0.0001 percent of boron was sensitive to prior thermal history. The hardenability of this steel was first impaired and then restored to its normal value by certain heat treatments.

Boron was lost in the decarburized zone of commercial steels. Evidence indicated that the diffusion rate of boron in austenite is of the same order of magnitude as that of carbon.

A boron constituent was observed in specially treated specimens of the iron-carbon and ironcarbon-manganese alloys and in an iron-boron alloy with 0.011 percent of boron. It was not observed in similarly treated specimens of an ironboron alloy containing relatively high oxygen and 0.003 percent of boron (except possibly a trace in specimens initially packed carburized) or in some experimental boron-treated steels containing highsoluble nitrogen. Thus the number, size, and distribution of the boron-containing particles varied with the amount and form of the boron and also with the conditions used in heat treating the specimens. The presence or absence of a boron constituent as determined in the metallographic test often indicated the response in hardenability of the alloy or steel to the boron treatment, but the test was not always a reliable criterion of this effect.

The effectiveness of boron in increasing the hardenability of certain alloys and steels is believed to be due to its action in retarding the rate of nucleation of ferrite and carbide while in solid solution in austenite.

The authors are indebted to Ellen H. Connelly and G. De Vries, former members of the section, for assistance in preparing the high-purity alloys and in carrying out some of the tests. The spectrographic analyses were made by C. H. Corliss, chemical analyses by J. L. Hague and K. D. Fleischer and gas analyses by J. T. Sterling. 


\section{References}

[1] T. G. Digges and F. M. Reinhart, J. Research NBS 39, 67 (1947) RP1815.

[2] M. Hansen, Der Aufbam der Zweistofflegierungen (von Julius Springer, Berlin, 1936). (Iron-boron system, fig. 127, p. 274).

[3] International Critical Tables $\mathbf{2 ,} 450$.

[4] R. A. Grange and T. M. Garvey, Trans. Am. Soc. Metals 3\%, 136 (1946).

[5] T. W. Lippert, Iron Age 150, 41 (Nov. 19, 1942).

[6] H. T. Chandler and M. A. Bredig, discussion of paper by Grange and Garvey [4].

[7] M. G. Corson, discussion of paper by Grange and Garvey [4].

[8] H. A. Allen, Steel 112, 67 (Feb. 15, 1943).

[9] R. S. Dean and B. Silkes, Boron in iron and steel, Information Circular, Bureau of Mines [IC 73 63] (Sept. 1946).

[10] G. H. Boss, Metal Progress 51, 265 (Feb. 1947).

[11] M. A. Grossmann, Hardenability calculated from chemical composition, Metals Tech. (June 1942) TP1437.

[12] Preparation of micrographs of metals and alloys, Am. Soc. Testing Materials Designation: E2-44T, Am. Soc. Testing Materials Standards, part I, Metals, p. 1875 (1944).

[13] S. J. Rosenberg and T. G. Digges, Trans. Am. Soc. Metals 29, 638 (1941); J. Research NBS 25, 215 (1940) RP1322.
[14] H. J. French, Trans. Am. Soc. Steel Treating 1\%, 798 (1930).

[15] A. L. Boeghold and E. W. Weinman, Metal Progress 51, 96-B (Jan. 1947).

[16] C. B. Post, M. C. Fetzer, and W. H. Fenstermacher, Trans. Am. Soc. Metals 35, 85 (1945).

[17] Tentative method of end-quench test for hardenability of steel, Am. Soc. Testing Materials Designation A 255-42T, Am. Soc. Testing Materials Standards, part I, Metals, p. 1106 (1942).

[18] M. A. Grossmann, M. Asimow, and S. F. Urban, Hardenability, its relation to quenching and some quantitative date, Hardenability of alloy steels, p. 125 (Published by the Am. Soc. Metals, 1939).

[19] United States Steel Corp., Research Laboratory, Atlas of isothermal transformation diagrams (1943).

[20] T. G. Digges, Trans. Am. Soc. Metals 29, 285 (1941); J. Research NBS 24, 723 (1940) RP1308.

[21] G. D. Rahrer and C. D. Armstrong, Trans. Am. Soc. Metals 40, 1099 (1948).

[22] A. B. Greninger and A. R. Troiano, Trans. Am. Soc. Metals 28, 537 (1940).

[23] N. Tschischewski, J. Iron Steel Inst. 95, 185 (1917).

[24] T. P. Campbell and H. Fay, Ind. Eng. Chem. 16, 719 (1924).

[25] Robert F. Mehl, Trans. Am. Soc. Metals 29, 825 (1941). 

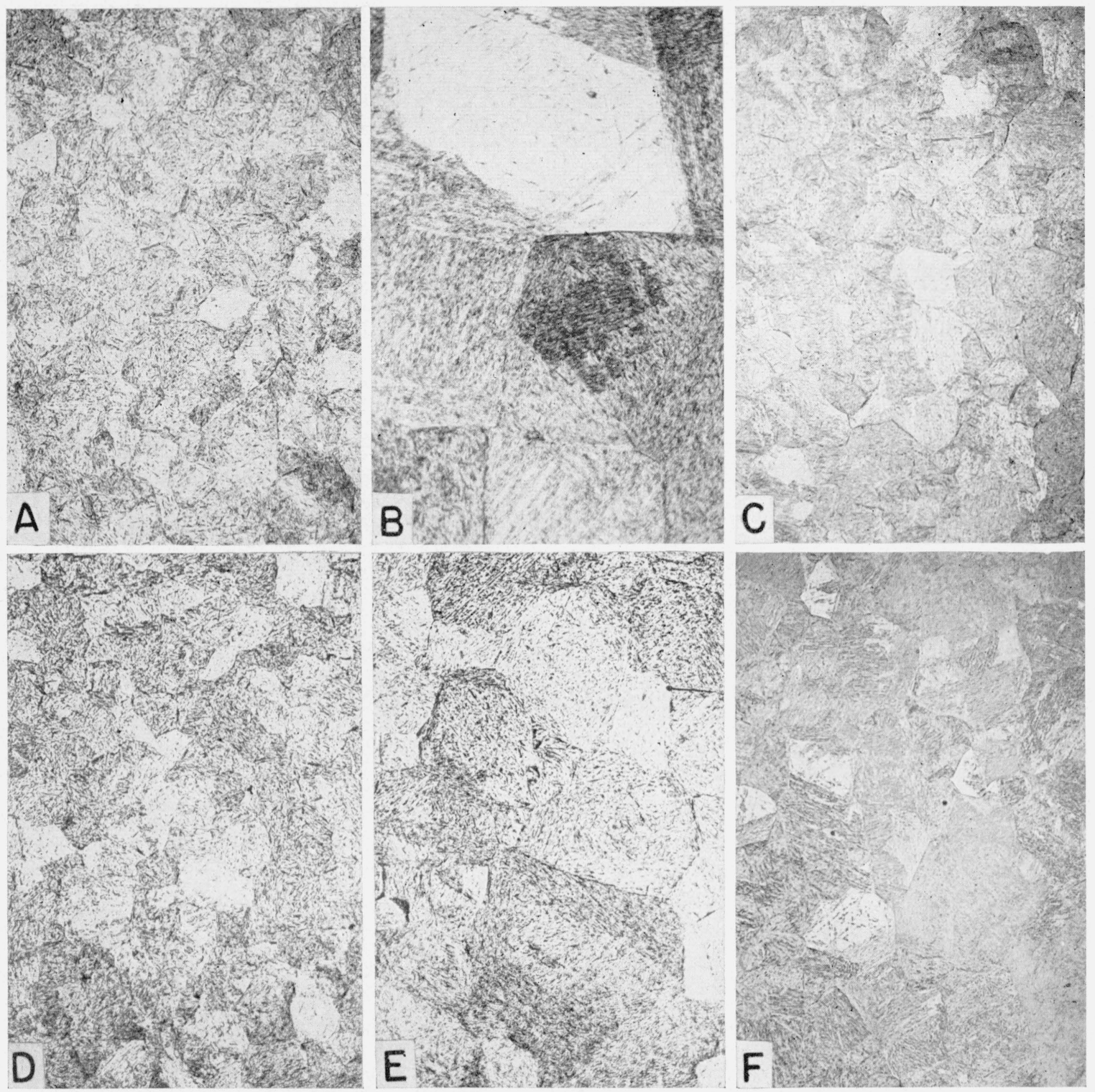

FIGURE 1. Effects of boron and temperature on the austenite grain size of high-purity alloys.

Etched with 1-percent picric-5-percent hydrochloric acid in alcohol, $\times 100$.

\begin{tabular}{|c|c|c|c|c|c|c|}
\hline \multirow{2}{*}{ Figure } & \multirow{2}{*}{ Alloy } & \multicolumn{3}{|c|}{ Percentage of- } & \multirow{2}{*}{$\begin{array}{c}\text { Tempera- } \\
\text { ture }\end{array}$} & \multirow{2}{*}{$\begin{array}{c}\text { ASTM } \\
\text { grain No. }\end{array}$} \\
\hline & & $\mathrm{C}$ & B & $\mathrm{Al}$ & & \\
\hline A... & B14 & 0.41 & 0.0024 & 0.003 & $\begin{array}{l}{ }^{\circ} \mathrm{F} \\
1,500\end{array}$ & 4 \\
\hline $\mathrm{B}_{-}$ & B14 & .41 & .0024 & .003 & 2,000 & 0 \\
\hline $\mathrm{C}_{2}$ & B12 & .54 & None & $<.001$ & 1,800 & 4 \\
\hline $\mathrm{D}_{\ldots}$ & B2 & .47 & 0.0020 & Not detected & 1,800 & 4 \\
\hline $\mathrm{E}_{-}$. & B2 & .47 & .0020 & Not detected & 1,800 & $1^{-}$ \\
\hline$F_{\ldots} \ldots$ & B12 & .54 & None & $<0.001$ & 1,800 & 3 \\
\hline
\end{tabular}






FIGURE 2. Effects of rate of heating, temperaiure, and time at temperature on the austenite grain size of the 0.42-percentcarbon-0.6\%-percent-manganese alloy without boron (B13)

A, B, C,-Photomicrographs of specimens, 1 in. in diameter by 4 in. long, heated relatively slowly to $1,500^{\circ}, 1,700^{\circ}$, or $1,900^{\circ} \mathrm{F}$, respectively, and held at temperature for 30 to $35 \mathrm{~min}$ (in furnace for $45 \mathrm{~min}$ ); etched with 1-percent nital, x100. D, E, F-Photomicrographs of specimens, $1 / 10$ by $1 / 10$ by 0.04 in., heated relatively rapidly to $1,500^{\circ}, 1,700^{\circ}$, or $1,900^{\circ} \mathrm{F}$, respectively, and held at temperature for 15 min (in furnace for 17 min); etched with 1 -percent picric-5-percent hydrochloric acid in alcohol, x100. 


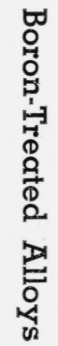

A

B

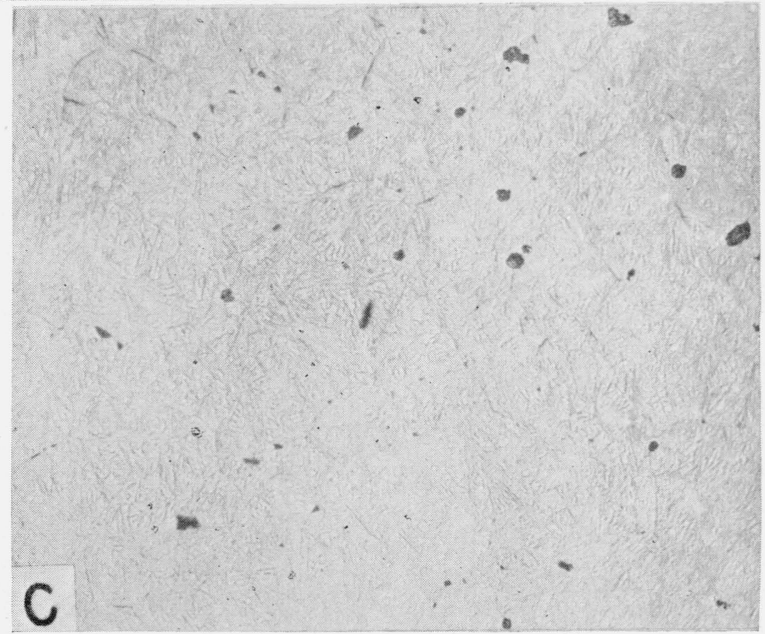

FIGURE 3. Photomicrographs used as a "standard" for estimating the amounts of fine pearlite in the quenched specimens.

Pearlite (dark) in a matrix of martensite, Etched with 1-percent nital, x100, A, Trace pearlite: B, 0.2-percent pearlite (amout corre sponds to that produced when the specimen was cooled at the "critical rate"); C, 1.0-percent pearlite.

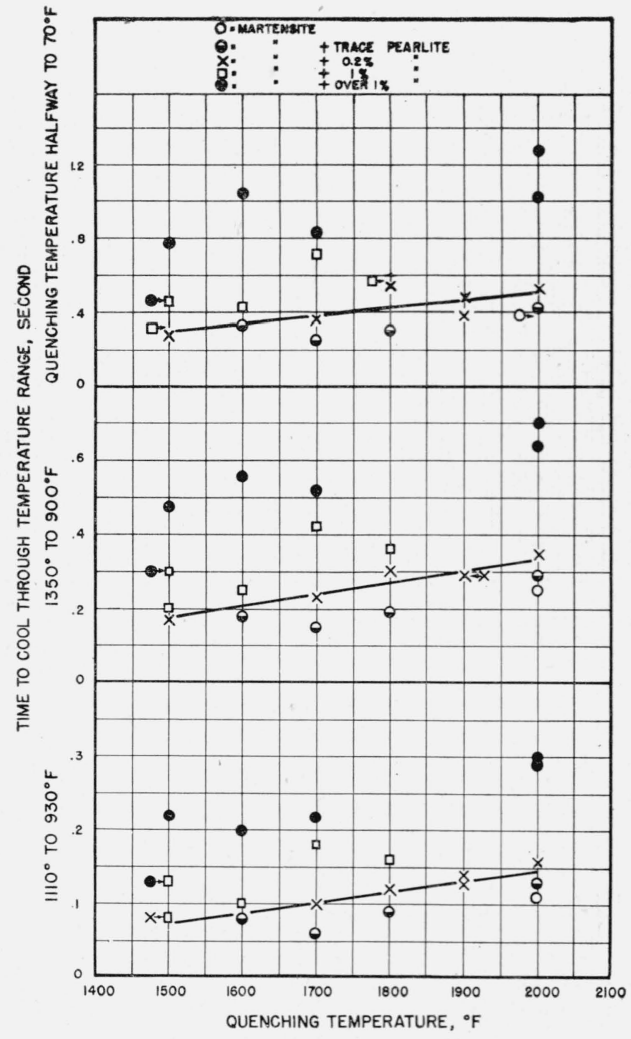

Figure 4. Effect of cooling time on the structure of the 0.32-percent-carbon alloy (B8) quenched from different temperatures.

The specimens were prepared from a homogenized bar. 


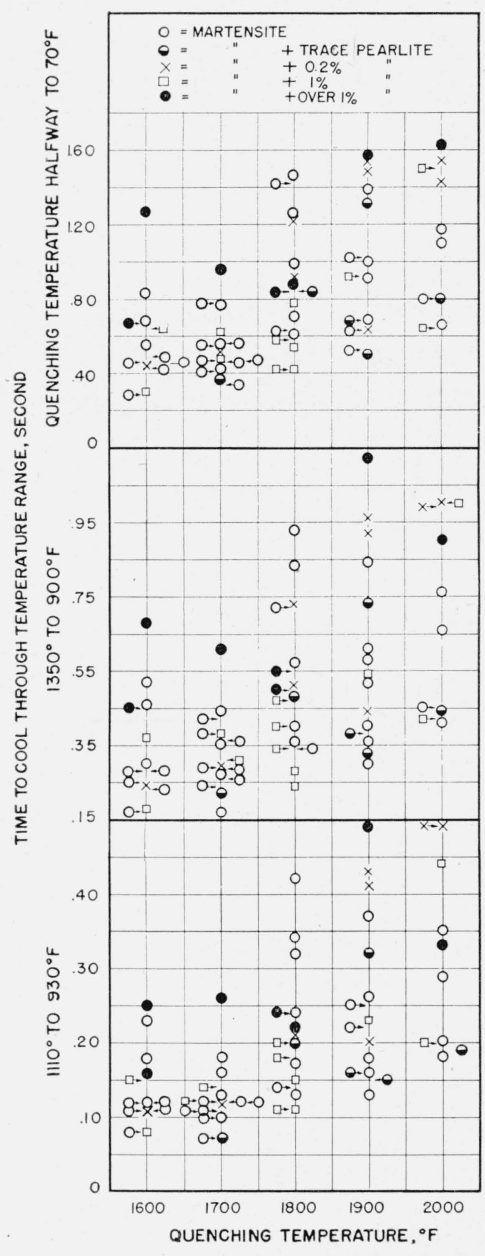

Figure 5. Effect of cooling time on the structure of the 0.32percent - carbon 0.0021 - percent boron alloy $(B 6)$ quenched from different temperatures.

The specimens were prepared from a homogenized bar.

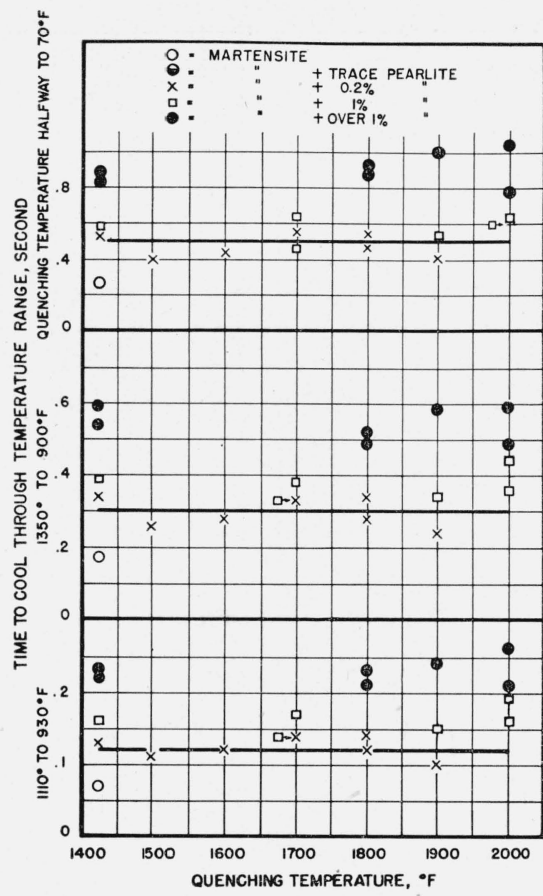

FIGURE 6. Effect of cooling time on the structure of the 0.50 -percent-carbon alloy $\left(B^{7}\right)$ quenched from different temperatures.

The specimens were prepared from a homogenized bar.

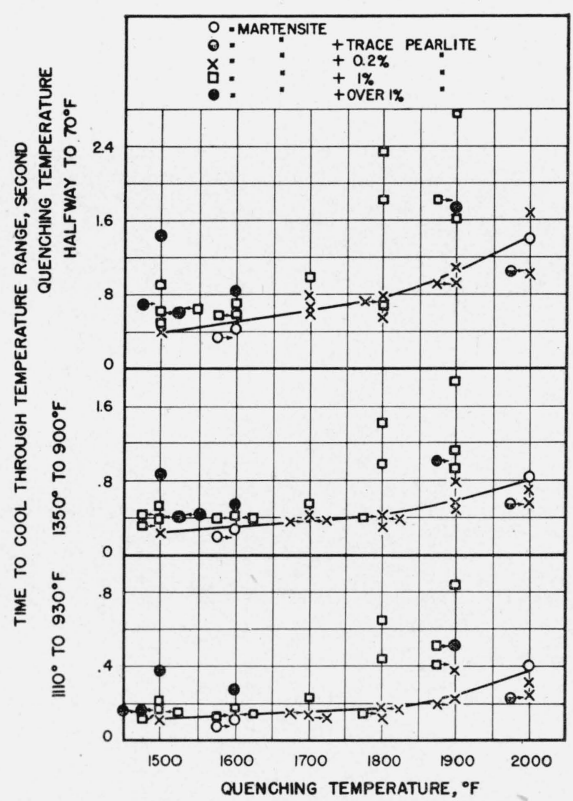

Figure 8. Effect of cooling time on the structure of the 0.4\%-percent carbon, 0.0020-percent-boron alloy (B2) quenched from different temperatures.

The specimens were prepared from a homogenized bar. 

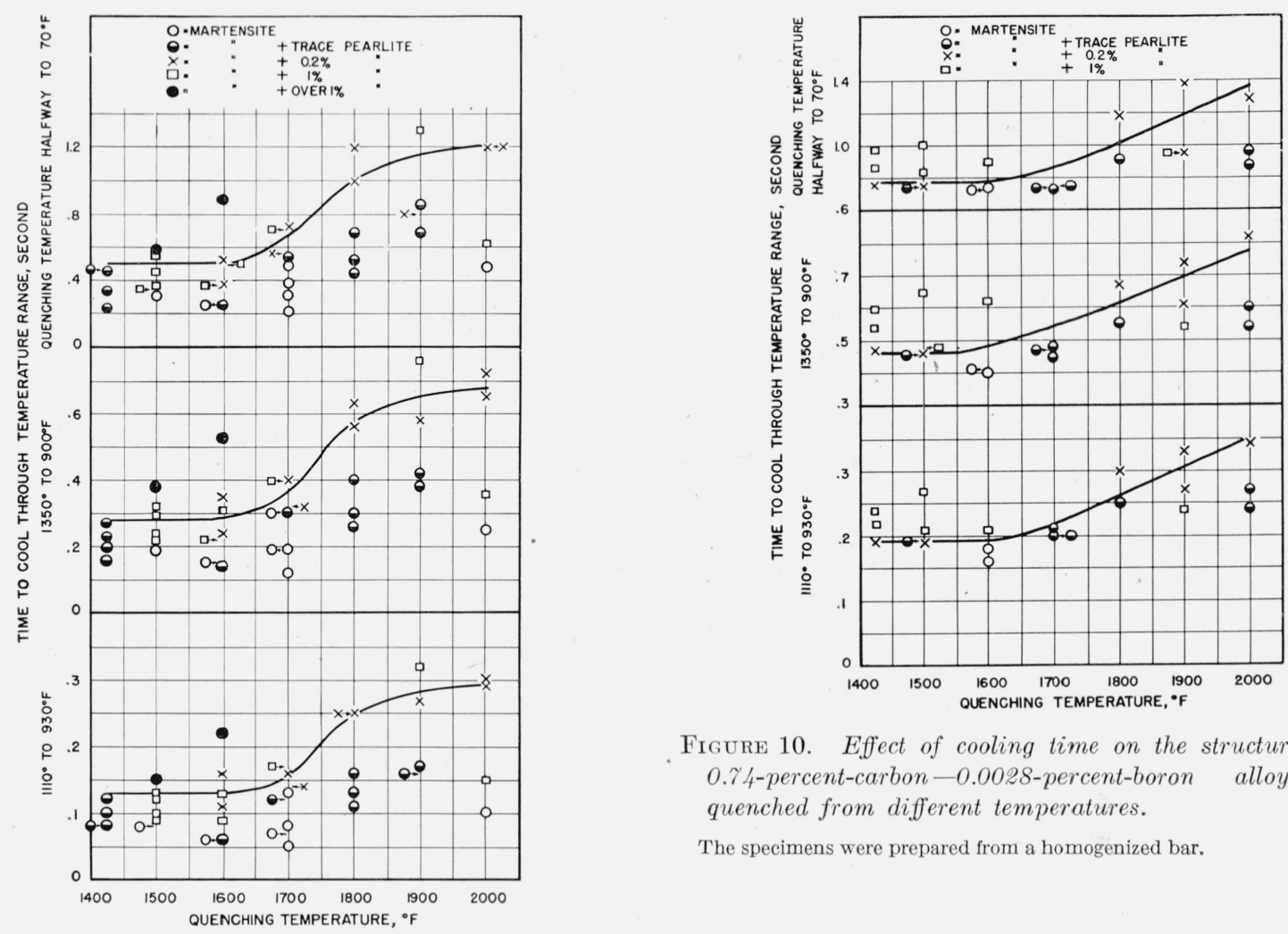

Figure 10. Effect of cooling time on the structure of the 0.74-percent-carbon-0.0028-percent-boron alloy I(B5) quenched from different temperatures.

The specimens were prepared from a homogenized bar.

Figure 9. Effect of cooling time on the structure of the 0.70percent-carbon alloy (B10) quenched from different temperatures.

The specimens were prepared from a homogenized bar.

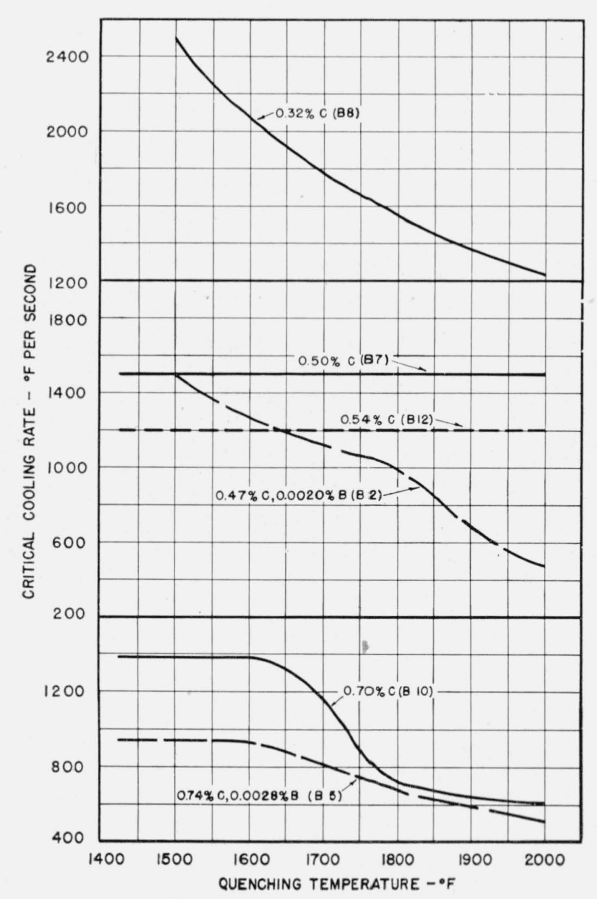

Boron-Treated Alloys

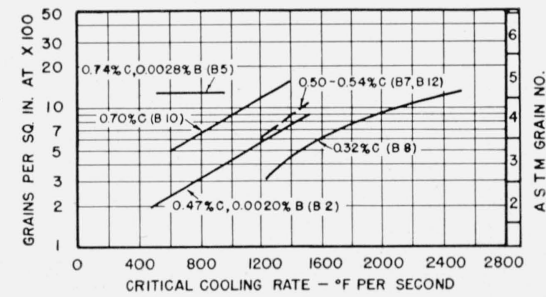

Figure 12.-Relation of critical cooling rate to austenite grain size of the ironcarbon alloys.

The specimens were prepared from homogenized bars.

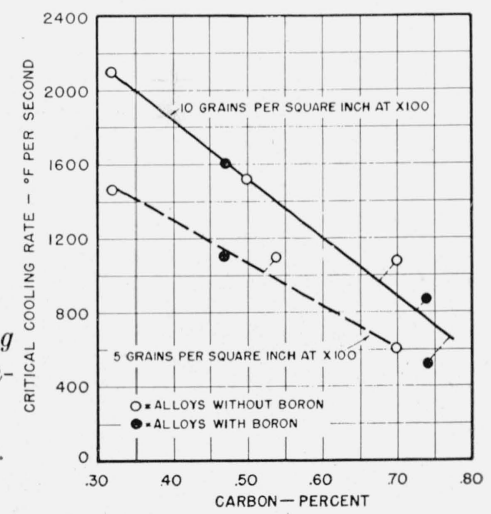

Figure 13. Relation of critical cooling rate to carbon content of the iron-carbon alloys.

The specimens were prepared from homogenized bars.

Figure 11. Relation of critical cooling rate to quenching temperature of the iron-carbon alloys.

The specimens were prepared from homogenized bars. Austenite grain size of the alloys is given in table 2. 


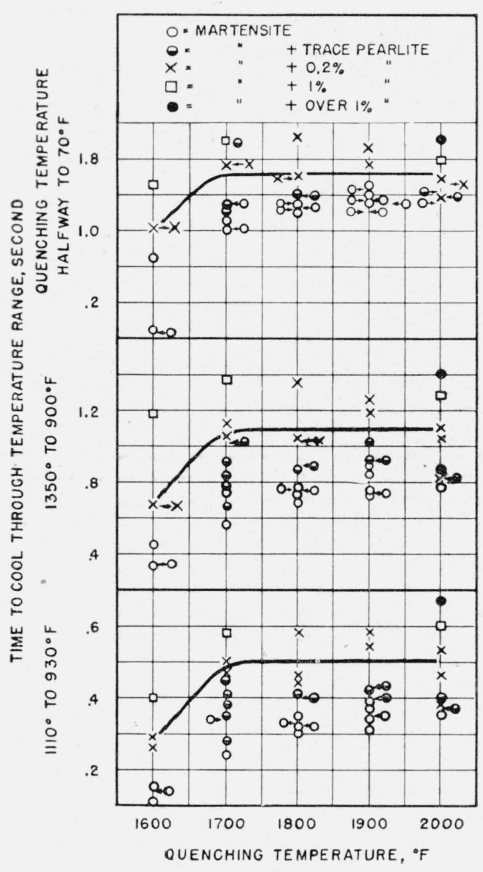

Figure 14. Effect of cooling time on the structure of the 0.32-percentcarbon-0.0021-percent-boron alloy (B6) quenched from different temperatures.

The specimens were prepared from the ingot.

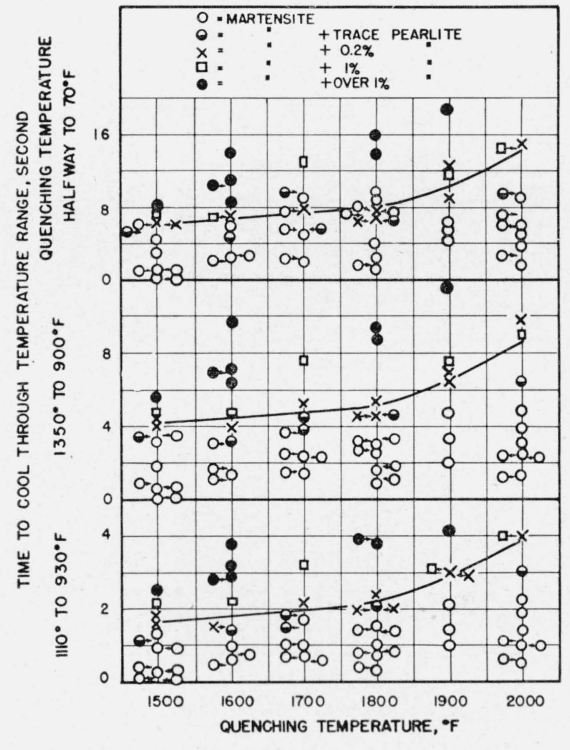

Figure 17. Effect of cooling time on the structure of the 0.41-percent-carbon0.64-percent-manganese-0.0024-percent-boron alloy (B14) quenched from different temperatures.

The specimens were prepared from a homogenized bar.

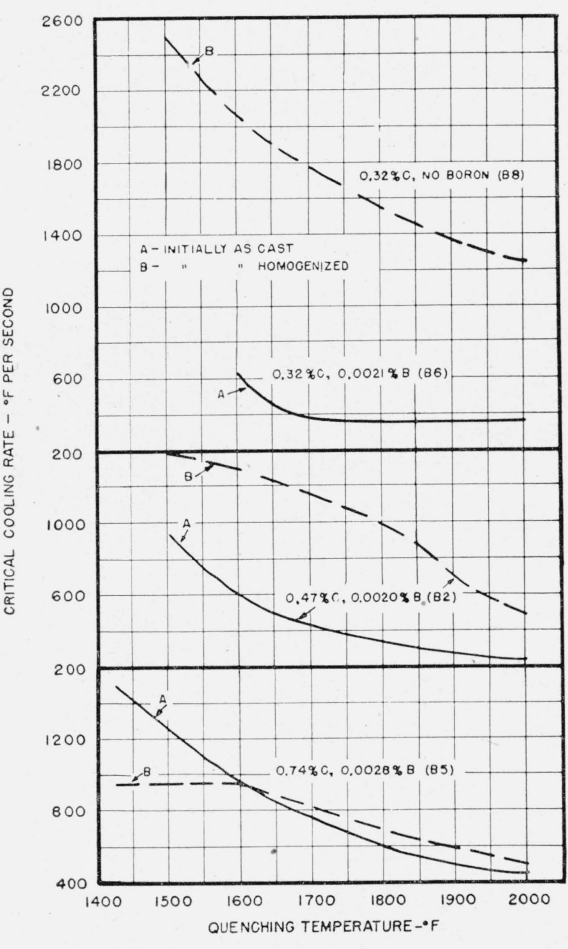

Figure 15. Relation of critical cooling rate to quenching temperature of some of the iron-carbon alloys.

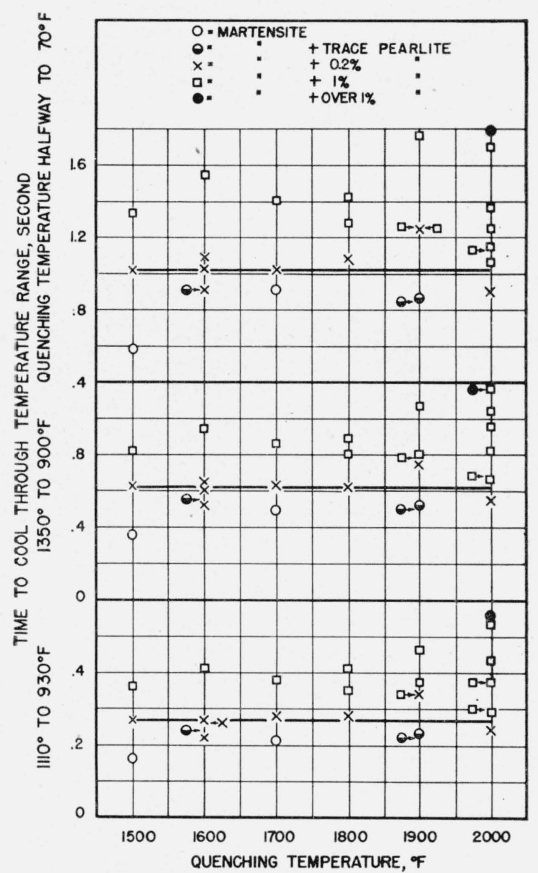

Figure 16. Effect of cooling time on the structure of the 0.42-percentcarbon-0.6\%-percent-manganese alloy (B13) quenched from different temperperatures.

The specimens were prepared from a homogenized bar.

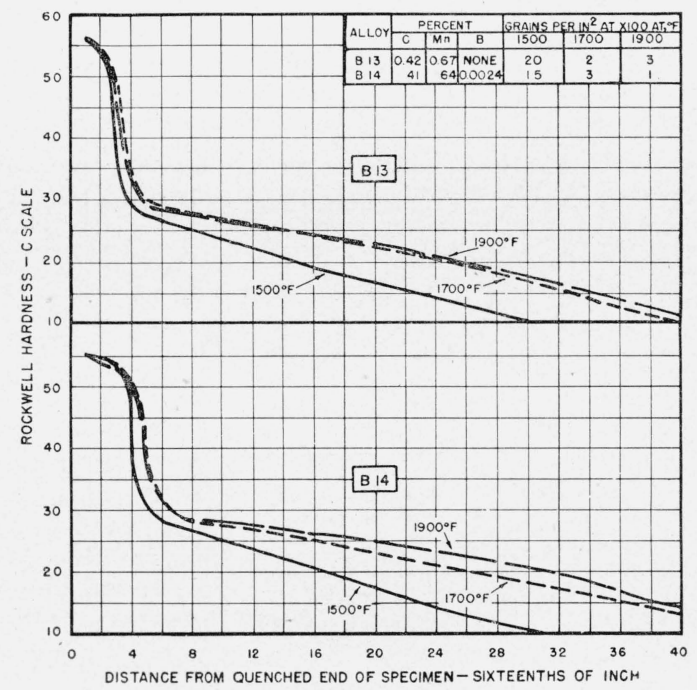

Figure 18. Hardenability curves of the ironcarbon-manganese alloys.

The specimens were normalized at $1,650^{\circ} \mathrm{F}$ before end-quenching from temperature as indicated. 
Figure 19. Relation of quenching temperature to the hardenability of the iron-carbon-manganese alloys.

The specimens were prepared from homogenized bars. Austenite grain size of the specimens used for determining the critical cooling rate is given in table 2 and for the end-quenched bars in figure 18.
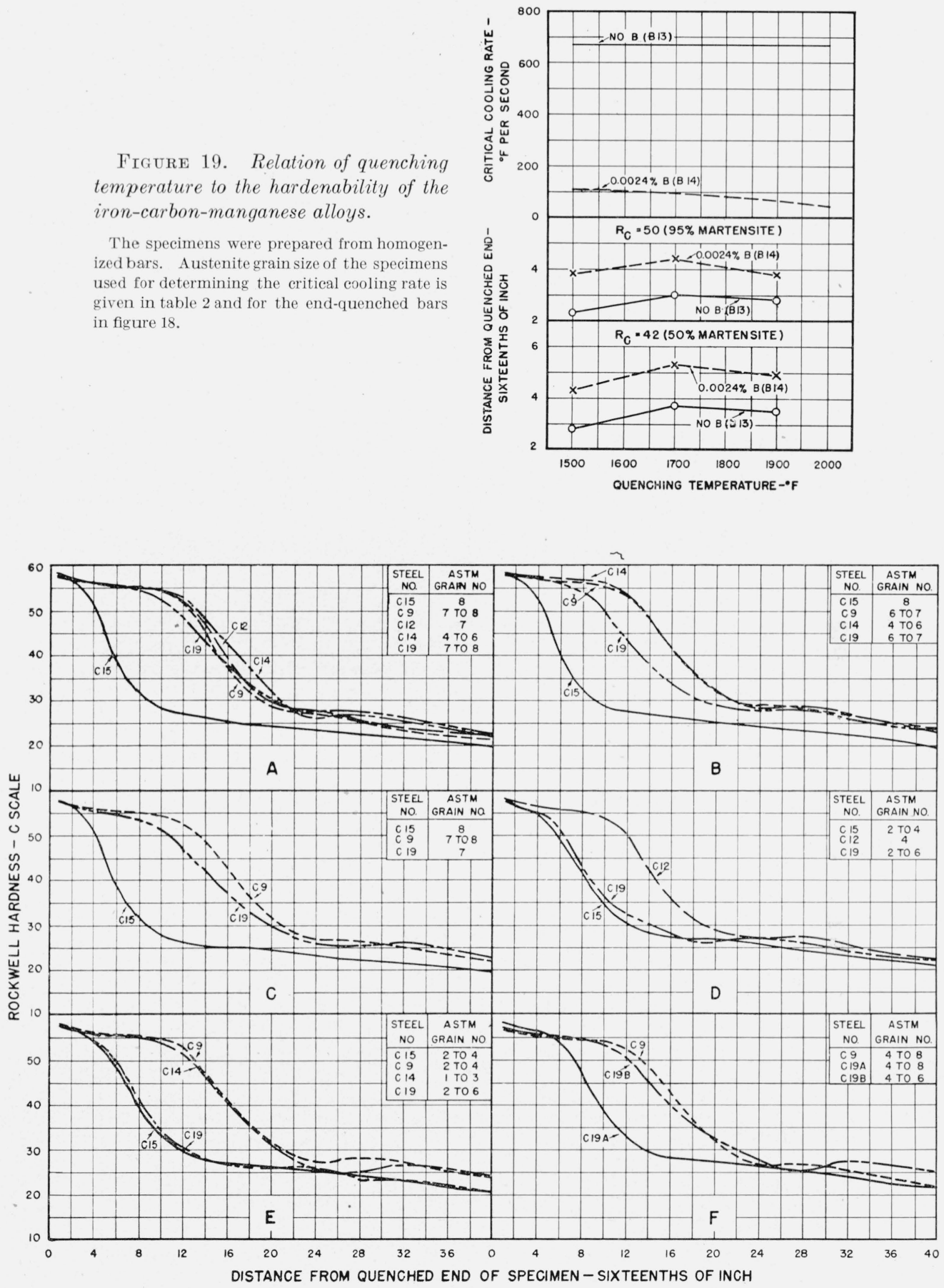

FIGURE 20. Effect of prior history on the hardenability as determinedin the end-quench test of some commercial steels containing 0.43 percent of carbon and 1.6 percent of manganese.

Steel C15 without boron; C9, 0.0003 percent of B (grainal No. 79); C12, 0.0022 percent of B (ferroboron); C14, 0.0036 percent of B (ferroboron); C19, 0.0001 percent of B (grainal No.1). All specimens were held for $45 \mathrm{~min}$ in the furnace at temperature just prior to end-quenching except as indicated. A, Specimens normalized at $1,650^{\circ} \mathrm{F}$ before end-quenching from $1,550^{\circ} \mathrm{F}$; B, specimens normalized at $1,900^{\circ} \mathrm{F}$ before end-quenching from $1,550^{\circ} \mathrm{F}$; $\mathrm{C}$, specimens quenched from $1,900^{\circ} \mathrm{F}$ in water before end-quenching from $1,550^{\circ} \mathrm{F}$; D, specimens normalized at $1,650^{\circ} \mathrm{F}$ reheated to $1,900^{\circ} \mathrm{F}$, then eooled to $1,550^{\circ} \mathrm{F}$ and held for 30 min before end-quenching; $\mathrm{E}$, specimens normalized at $1,650^{\circ} \mathrm{F}$, reheated to $1,900^{\circ} \mathrm{F}$, then cooled to $1,425^{\circ} \mathrm{F}$ and held for 30 min before end-quenching; $\mathrm{F}$, specimens normalized at $1,650^{\circ} \mathrm{F}$, reheated to $1,900^{\circ} \mathrm{F}$, then cooled to $1,425^{\circ} \mathrm{F}$ and held for 30 min then quenched in water. The specimens were then treated as follows: Specimens $\mathrm{C} 19 \mathrm{~A}$ and $\mathrm{C} 9$ reheated to $1,550^{\circ} \mathrm{F}$ and end-quenched; specimen $\mathrm{C} 19 \mathrm{~B}$ reheated to $1,750^{\circ} \mathrm{F}$ and end-quenched. 
Figure 21. Effect of quenching temperature on the temperature of the start of the transformation of austenite to martensite in a commercial steel containing 0.43 percent of carbon, 1.6 percent of manganese, and 0.0036 percent of boron $\left(\mathrm{C1}_{4}\right)$.

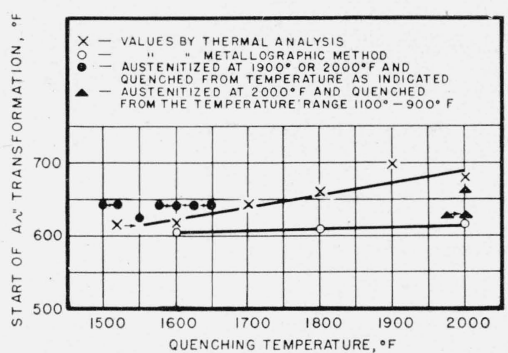

The average size of the austenite grains ranged from about American Society for Testing Materials number 5 to 2 with change in temperature from $1,550^{\circ}$ to $2,000^{\circ} \mathrm{F}$.

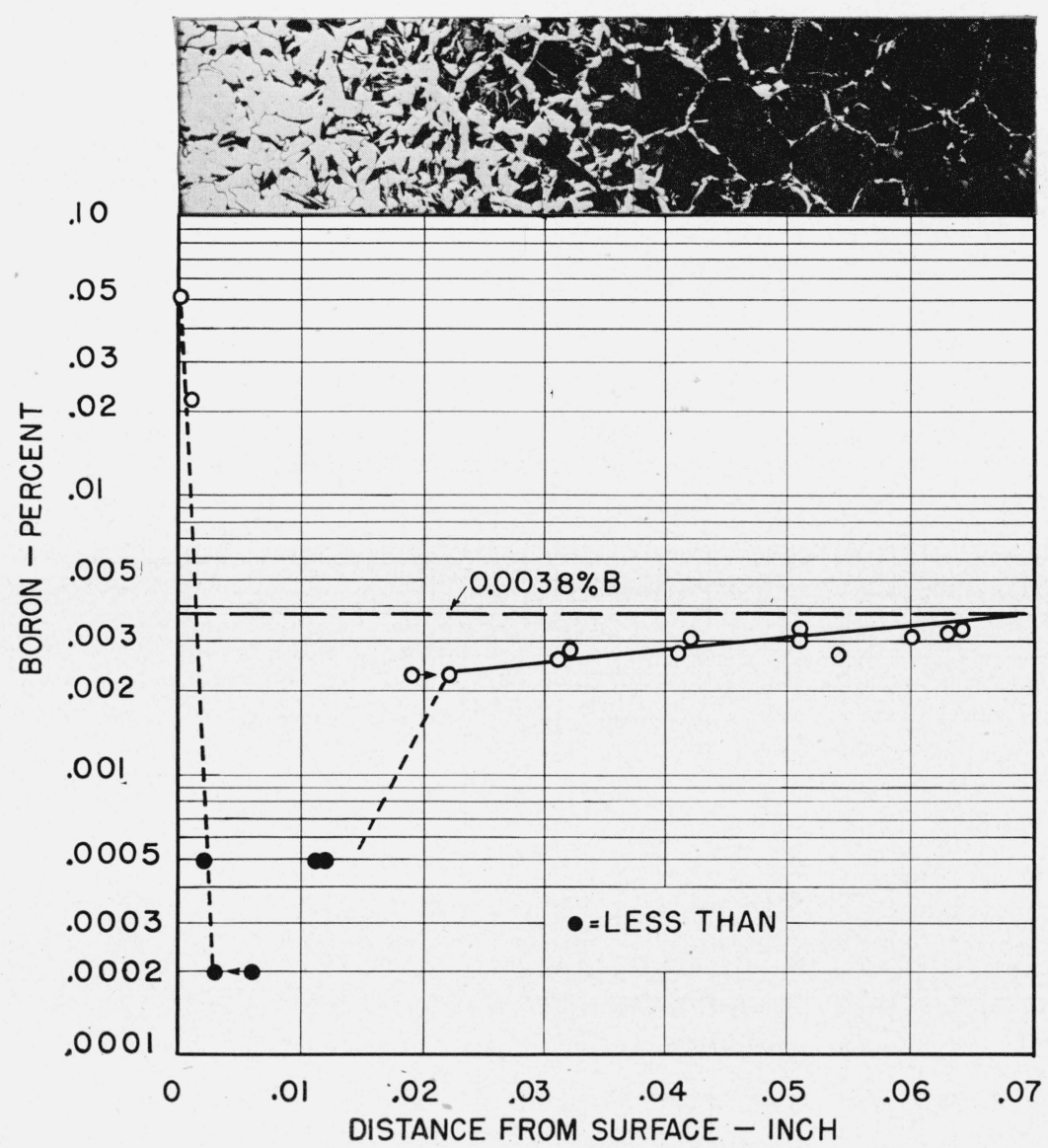

FIGURE 22. Distribution of boron in a decarburized layer of a commercial boron-treated steel (C14).

The specimen was decarburized by heating in a furnace (reducing atmosphere) at $1,900^{\circ} \mathrm{F}$ for $8 \mathrm{hr}$ and then cooling in mica. The left edge of the photomicrograph corresponds to the original surface of the specimen, and the characteristic structure (not decarburized) is shown at the right, etched with 1 percent-nital, $\times 100$ (reduced approximately one-half in reduction). Determination for boron by spectrographic analysis was made on the heat-treated specimen at the surface and at various levels below this surface; the successive levels were obtained by progressive grinding. The nominal boron content of steel C14 was 0.0038 percent (heavy horizontal line) as determined spectrographically. 

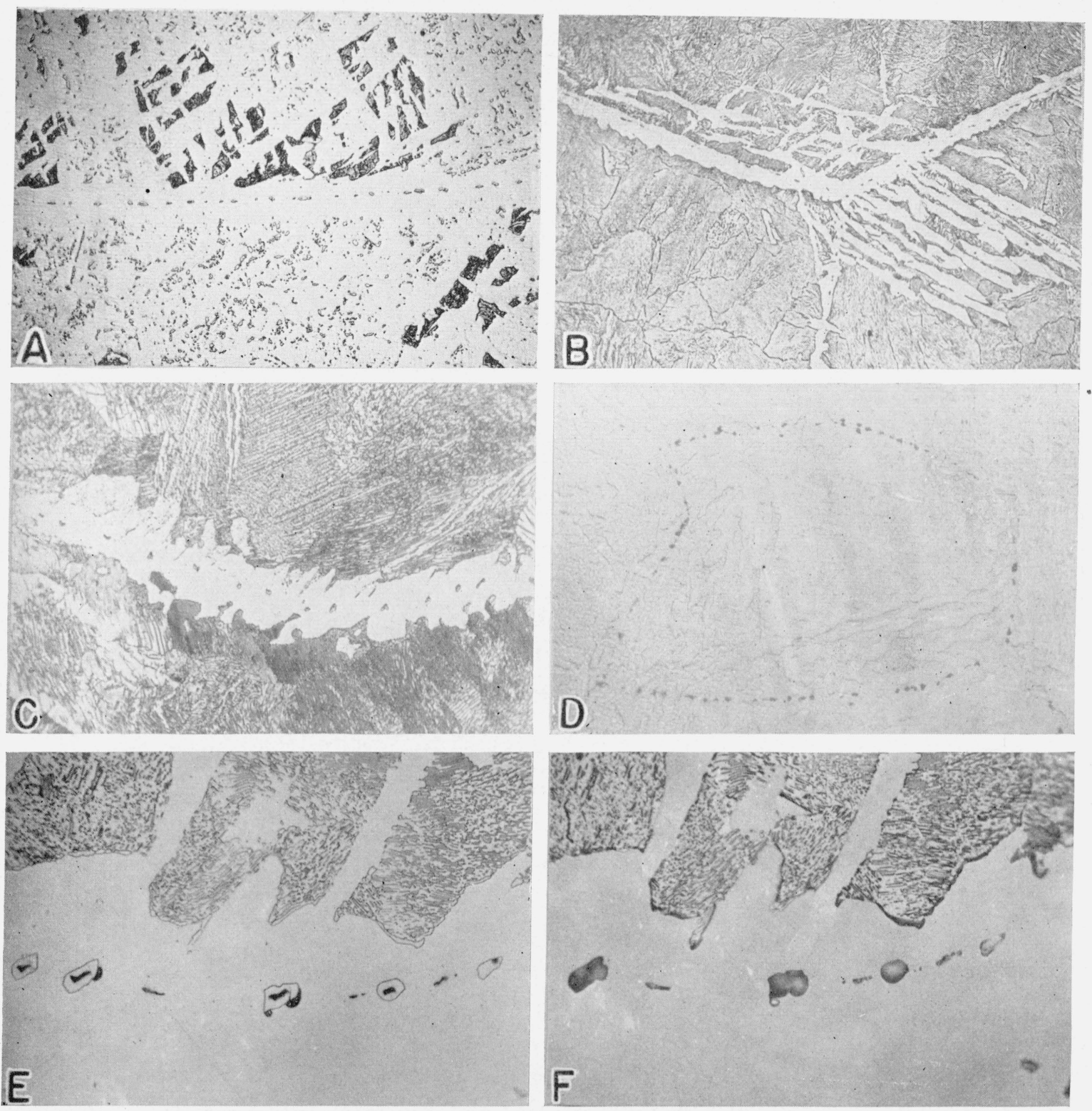

FIgURE 23. Typical structures of boron-treated alloys as cast or as homogenized.

A, Alloy (B6) containing 0.32 percent of carbon and 0.0021 percent of boron as cast. Ferrite (white) located in primary austenite grain boundaries contains spheroidized carbides; some spheroidization of carbides occurred during the cooling of the ingot, etched with 4-percent picral, $\times 100$. B, alloy (B2) containing 0.47 percent of carbon and 0.0020 percent of boron as cast, etched with 4-percent picral, $\times 100$. C, alloy (B14) containing 0.41 percent of carbon, 0.64 percent of manganese, 0.0024 percent of boron as homogenized, etched with 1-percent nital, $\times 500$. D, alloy (B2) as cast, unetched, $\times 100$. E, alloy (B2) as cast, etched with 4-percent picral, $\times 500$. F, same area as $\mathrm{E}$, etched electrolytically with 10-percent sodium cyanide in water, $\times 500$. 

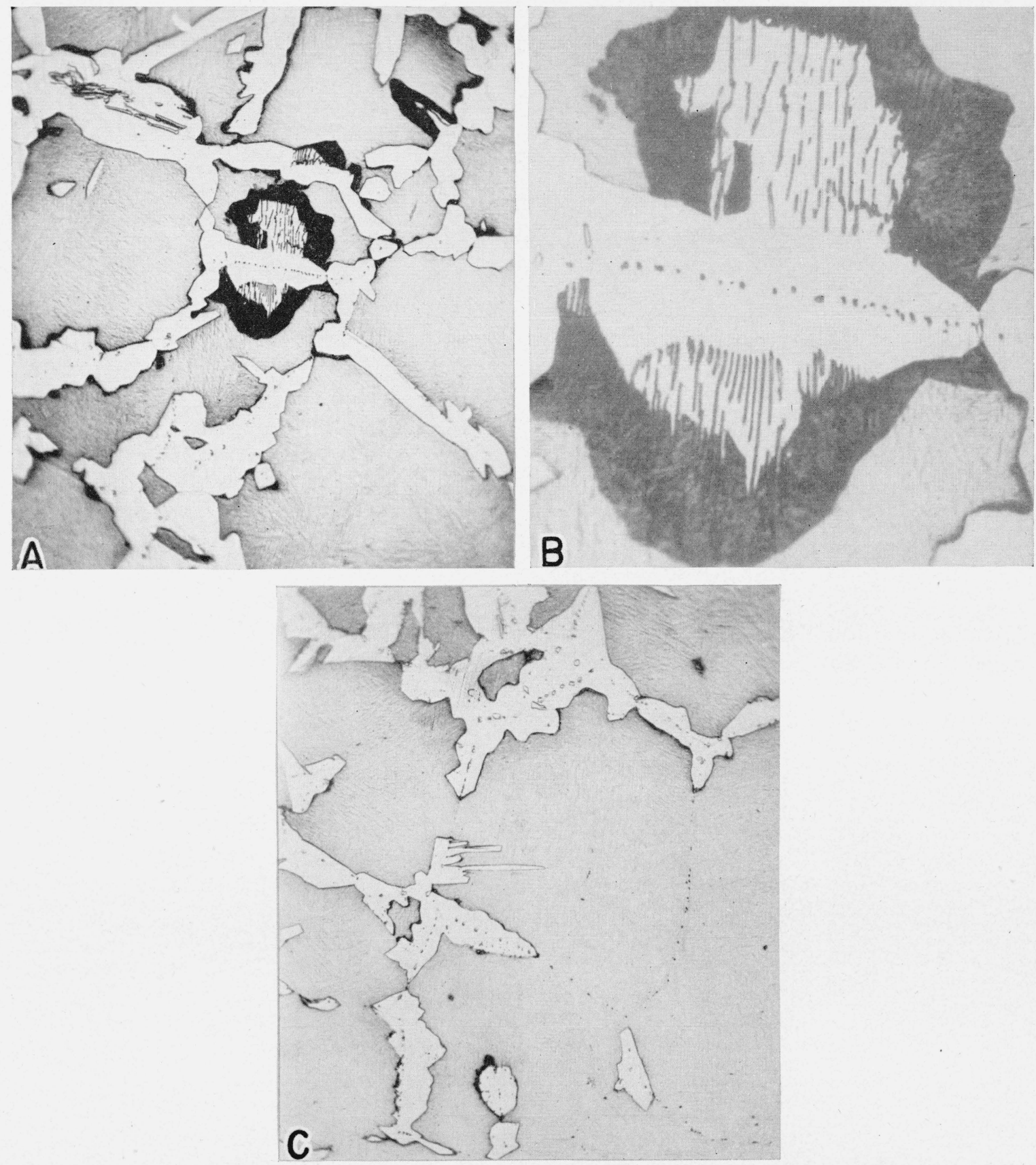

FiguRE 24. Structure produced in a quenched specimen of the 0.47 percent carbon-0.0020-percent boron alloy (B2).

A small specimen, initially as cast, was heated to $1,900^{\circ} \mathrm{F}$ for $3 \mathrm{~min}$ and then cooled in a lead bath at $1,300^{\circ} \mathrm{F}$ for 1 min., followed by quenching in a solution of sodium hydroxide in water at room temperature. Etched with 4-percent picral. A, ferrite network (light) containing some spheroid and elongated carbide particles, martensite (gray), coarse (laminated) and fine (dark) pearlite, $\times 500 ; \mathrm{B}$, pearlite area (shown near center of photomicrograph A) with spheroidized carbide particles extending nearly linearly across this area, $\times 2,000$; , partial network of ferrite containing carbide particles, martensitic matrix with a boron constituent (relatively fine and dark do: ), $\times 500$. Note the continuity in the alinement of the carbide and boron containing particles. 

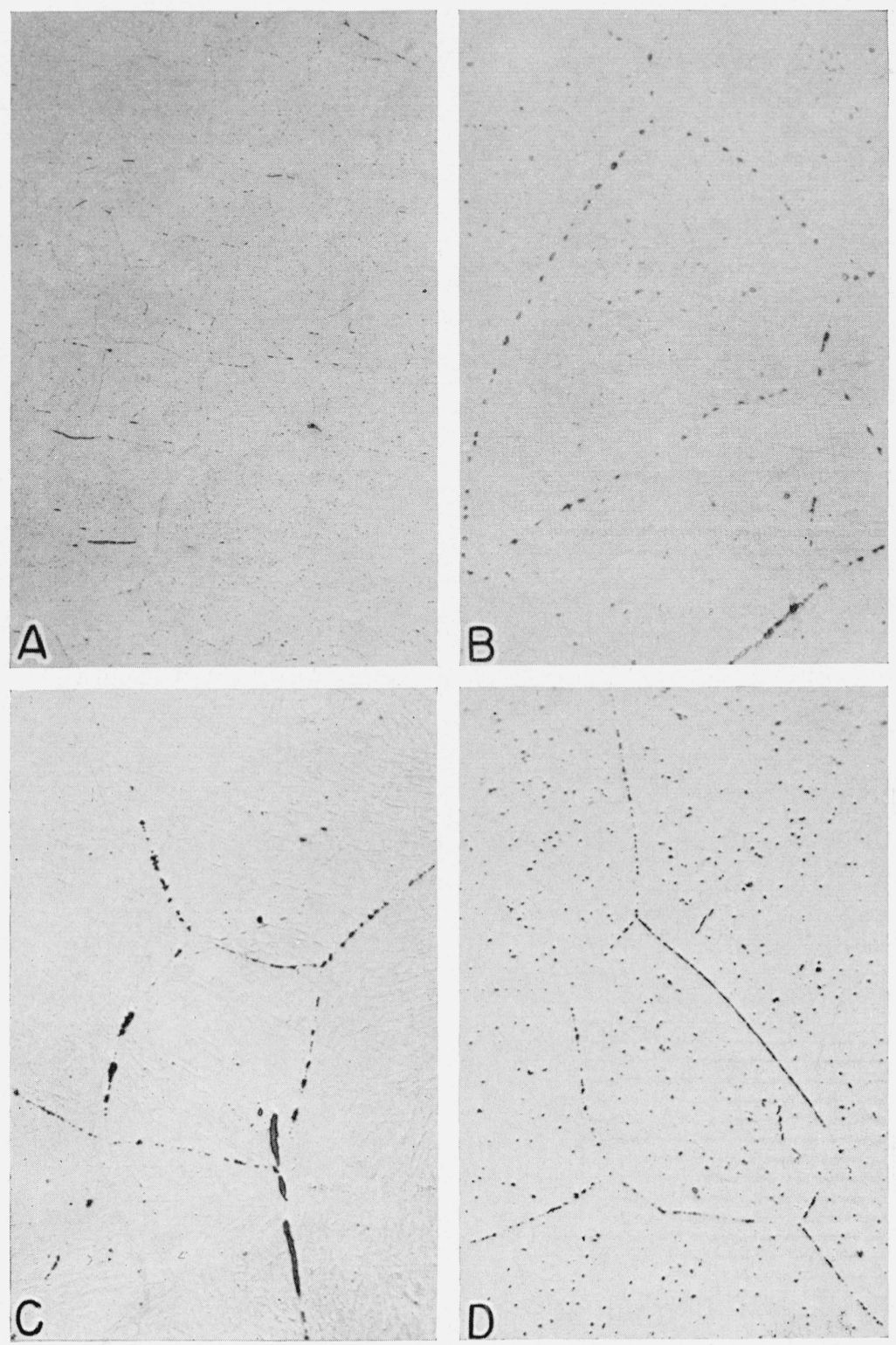

Figure 25. Boron constituent in a commercial steel (C14).

Etched with 4-percent picral. A, small specimen heated to $2,000^{\circ} \mathrm{F}$ for 20 min and then cooled in a lead bath at $1,200^{\circ} \mathrm{F}$ for 2 min, followed by quenching in water at room temperature. The boron constituent (dark etching dots) is located principally in the parent austenite grain boundaries, $\times 100$; B, same specimen as $\mathrm{A}, \times 500$; C, small specimen heated to $2,000^{\circ} \mathrm{F}$ for $20 \mathrm{~min}$ and then quenched in iced sodium hydroxide water-solution, $\times 500$; $\mathrm{D}$, same specimen as $\mathrm{C}$. Note the boron constituent also within the grains, $\times 500$. 

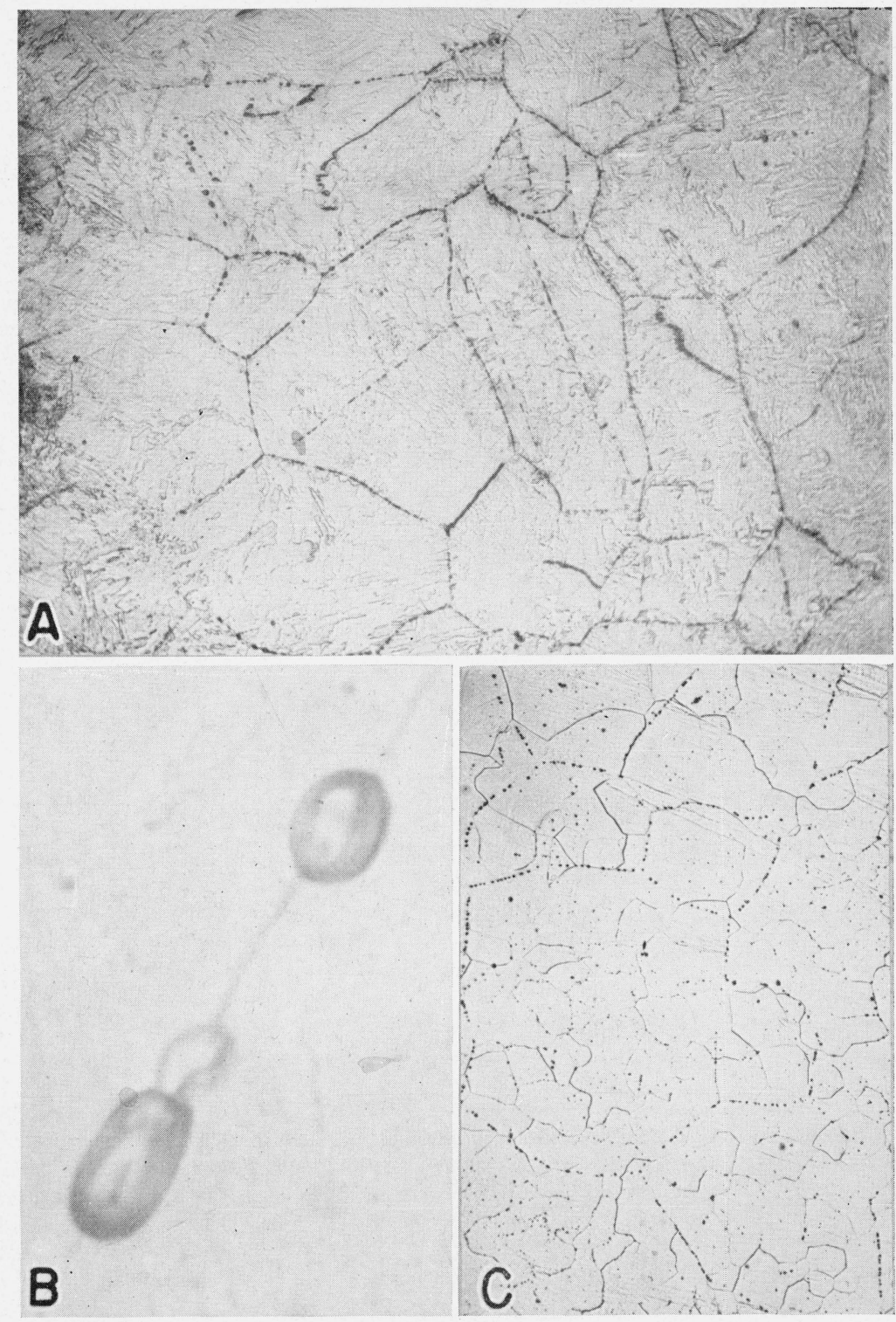

FIGURE 26. Boron constituent in at high-puriy iron-boron alloy (B4).

Etched with 4-percent picral. A, small specimen, initially as cast, heated to $2,000^{\circ} \mathrm{F}$ for $3 \mathrm{~min}$, and then cooled in a lead bath at $1,700^{\circ} \mathrm{F}$ for 5 min followed by quenching in sodium hydroxide solution at room temperature. The left edge of the photomicrograph corresponds to the original surface of the specimen. Note the boron constituent (dark etching dots) located in the parent grain boundaries and in parallel planes within some of the grains; it does not extend to the original surface of the specimen, $\times 100 ; \mathrm{B}$, same specimen as $\mathrm{A}, \times 4,000$; $\mathrm{C}$, same specimen as $\mathrm{A}$ after reheating in a lead bath at $1,650^{\circ} \mathrm{F}$ for 5 min and then quenched in sodium hydroxide solution, $\times 100$.

Washington, July 7, 1948. 